NBER WORKING PAPER SERIES

\title{
RISING IMPORT TARIFFS, FALLING EXPORT GROWTH: WHEN MODERN SUPPLY CHAINS MEET OLD-STYLE PROTECTIONISM
}

\author{
Kyle Handley \\ Fariha Kamal \\ Ryan Monarch \\ Working Paper 26611 \\ http://www.nber.org/papers/w26611 \\ NATIONAL BUREAU OF ECONOMIC RESEARCH \\ 1050 Massachusetts Avenue \\ Cambridge, MA 02138 \\ January 2020, Revised August 2020
}

The Census Bureau's Disclosure Review Board and Disclosure Avoidance Officers have reviewed this data product for unauthorized disclosure of confidential information and have approved the disclosure avoidance practices applied to this release (DRB Approval Numbers: CBDRB- FY19-519, CBDRB-FY20-104, CBDRB-FY20-CES006-004, CBDRB-FY20CES006-005). We thank Chad Bown, Teresa Fort, Colin Hottman, Soumaya Keynes, CJ Krizan, Frank Li, and seminar and conference participants at the Federal Reserve Board, University of Michigan, Mid-Atlantic International Trade Workshop, U.S. Census Bureau, Stanford University, University of Virginia, Georgetown University, George Washington University, IDB, Rowan University, and FREIT ETOS for helpful comments and discussions. Any opinions and conclusions expressed herein are those of the authors and do not necessarily represent the views of the U.S. Census Bureau, other members of the research staff at the Board of Governors, the Board of Governors of the Federal Reserve System, or the National Bureau of Economic Research.

NBER working papers are circulated for discussion and comment purposes. They have not been peer-reviewed or been subject to the review by the NBER Board of Directors that accompanies official NBER publications.

(C) 2020 by Kyle Handley, Fariha Kamal, and Ryan Monarch. All rights reserved. Short sections of text, not to exceed two paragraphs, may be quoted without explicit permission provided that full credit, including $(\odot$ notice, is given to the source. 
Rising Import Tariffs, Falling Export Growth: When Modern Supply Chains Meet Old-Style

Protectionism

Kyle Handley, Fariha Kamal, and Ryan Monarch

NBER Working Paper No. 26611

January 2020, Revised August 2020

JEL No. F1,F13,F14,F23,H2

\section{ABSTRACT}

We examine the impacts of the 2018-2019 U.S. import tariff increases on U.S. export growth through the lens of supply chain linkages. Using 2016 confidential firm-trade linked data, we identify firms that eventually faced tariff increases. They accounted for $84 \%$ of all exports and represented $65 \%$ of manufacturing employment. For the average affected firm, the implied cost is $\$ 900$ per worker in new duties. We construct product-level measures of exporters' exposure to import tariff increases and estimate the impact on U.S. export growth. The most exposed products had relatively lower export growth in 2018-2019, with larger effects in 2019. The decline in export growth in 2019Q3, for example, is equivalent to an ad valorem tariff on U.S. exports of $2 \%$ for the typical product and up to $4 \%$ for products with higher than average exposure.

Kyle Handley

Ross School of Business

University of Michigan

701 Tappan Street

Ann Arbor, MI 48109

and NBER

handleyk@umich.edu

Fariha Kamal

U.S. Bureau of the Census

4600 Silver Hill Road

Washington, D.C 20233

fariha.kamal@census.gov
Ryan Monarch

International Finance Division

Federal Reserve Board of Governors

20th Street and Constitution Avenue N.W.

Washington, D.C. 20551

ryan.p.monarch@frb.gov 


\section{Introduction}

The United States imposed a series of wide-ranging increases in import tariffs from 2018 through 2019. By August of 2019, $\$ 290$ billion of U.S. imports - about $12 \%$ of the total - were subject to an average tariff increase of 24 percentage points. ${ }^{1}$ The scale of these tariffs against specific products and countries, and the subsequent retaliation, has drawn comparisons to the Depression-era tariff wars of the 1930s. ${ }^{2}$ However, the structure of world trade has been substantially transformed since then, following reductions in trade costs and new communications technology (Baldwin, 2016). Global supply chains are a pervasive feature of world trade (Hummels, Ishii and Yi, 2001; Johnson and Noguera, 2017) and a potentially important channel of transmitting the impact of import tariffs to exports because they can amplify shocks to trade costs and demand across locations (Almunia, Antrás, Lopez-Rodriguez and Morales, 2018; Boehm, Flaaen and Pandalai-Nayar, 2019; Yi, 2003). We estimate and quantify the supply chain spillovers to export growth of increases in U.S. import tariffs.

Notably, U.S. export growth was weak from mid-2018 through late 2019. Figure 1 illustrates the average 12-month export growth rate for each quarter from 2017 and shows that export growth declined beginning in 2018 Q4. ${ }^{3}$ The drop in export growth extends beyond the major products and countries that were the focus of 2018-2019 trade tensions: the decline is clear even when progressively excluding products that ultimately face foreign retaliation; all remaining exports to China, Mexico, and Canada; and finally all remaining trade with Asia and Europe. The wide-ranging weakness in U.S. export growth underlines the importance of quantifying the supply chain spillovers of import tariffs.

We demonstrate that U.S. import tariffs weakened U.S. export growth leveraging confidential U.S. firm-trade linked data. First, we measure the firm-specific incidence of the tariffs. Then, we identify the set of exporters that are also importing products in the same category on which tariffs are ultimately imposed in 2018-2019 to construct measures of import tariff exposure for dis-aggregated export products. Finally, combined with official monthly public-use export data from 2015 through 2019, we estimate the impacts of exposure to increases in import tariffs. We find that supply chain spillovers from increased import tariffs

\footnotetext{
${ }^{1}$ The dollar value of tariffed imports is calculated on an annual basis using 2017 data, and the average tariff increase is weighted using the same data. For a timeline of tariffs on U.S. imports and foreign retaliatory export tariffs, see Bown and Kolb (2019).

${ }^{2}$ The Smoot-Hawley tariffs increased import duties by about $20 \%$ on average and set off a wave of worldwide protectionism (Irwin, 1998).

${ }^{3}$ For every month of U.S. export data and every destination country-HS 6-digit product pair, we compute the 12-month growth rate, then take the average within each quarter.
} 
dampened U.S. export growth over 2018-2019 for the typical affected export product, even after controlling for foreign-imposed retaliatory export tariffs.

Our findings are consistent with U.S. export growth weakening in response to newly imposed import tariffs that impacted firms' supply chain networks. U.S. tariff increases were disproportionately applied to intermediate goods that are typically inputs in production (Bown and Zhang, 2019). Lovely and Liang (2018) document that the Section 301 import tariffs taxed inputs for U.S. businesses via supply chain trade. Amiti, Redding and Weinstein (2019) estimate that $\$ 165$ billion in trade may have been lost when firms redirected trade in their supply chains to avoid tariffs. Our results are also consistent with business anecdotes. For example, in U.S. Senate testimony, the CEO of Learning Resources wrote: "We have business reasons for the assignment of products to specific factories, whether in the United States or in other countries. [...] We have also made repeated attempts to develop a U.S.based supply chain but cannot do so on any basis, even inefficiently. We have no known realistic alternative to our current supply chain." (U.S. Senate Committee on Finance, 2018). Caldara, Iacoviello, Molligo, Prestipino and Raffo (2019) find that when firms discussed tariffs and policy uncertainty on earnings calls in recent years, the primary concern cited was their supply chains. The Federal Reserve Beige Book (November 27, 2019) documents that "[...] firms have reported tariff impacts on sales, either in terms of pricing or in terms of supply chain disruptions slowing their product supply."

The first part of the paper documents tariff incidence within and across firms by linking the publicly available information on new tariffs to data on the operations of firms importing or exporting, in 2016, those products that would ultimately face tariff increases. ${ }^{4}$ About a third of all U.S. importers in 2016 traded product categories that would be exposed to the new import tariffs in 2018-2019 and they employed 32\% of all non-farm, private sector workers. About $19 \%$ of U.S. exporters faced retaliatory foreign export tariffs and they employed $23 \%$ of all non-farm, private sector workers. A non-trivial share of trade value was subject to tariff increases at the typical affected firm: $46 \%$ of an affected importer's purchases were subject to U.S. import tariffs; and $33 \%$ of an affected exporter's sales faced foreign export tariffs.

Next, we document important sources of heterogeneity across firms hit by new import and export tariff increases. We find that U.S. importers facing import tariff increases employed twice as many workers compared to the average importing firm and about nine times as many workers as the average firm. Similarly, we find that U.S. exporting firms facing

\footnotetext{
${ }^{4}$ Our exposure measures leverage trade patterns well before the 2016 presidential election outcome was known and prior to the anticipation of new tariffs throughout 2017.
} 
retaliatory tariffs were more than three times larger than the average exporting firm. Thus, the tariff increases hit the very largest trading firms in the U.S. economy.

The tariff costs are non-trivial for the average firm in the economy: assuming that tariffs remained in place for a full year and firms did not adjust sourcing strategies, the implied duties paid were $\$ 900$ per worker overall and about $\$ 1,600$ per worker in the manufacturing sector. Workers in manufacturing and retail were most exposed to the import tariff increases: $65 \%$ of employment in manufacturing and $60 \%$ of employment in retail was at firms facing higher import tariffs.

The vast majority of U.S. trade is conducted by firms that both export and import. ${ }^{5}$ We find that, based on 2016 trade flows, U.S. exporters exposed to import tariffs in the same broad product category as their exports - products mostly likely to be part of a supply chain - accounted for $43 \%$ of total U.S. exports and $24 \%$ of all U.S. exporters. Considering U.S. exporters exposed to any import tariff, the share of affected export value nearly doubles to $84 \%$.

We aggregate individual U.S. exporters' exposure to increases in import tariffs to construct product level measures of import tariff exposure. We then estimate the impact of import tariff exposure on U.S. export growth in a generalized difference-in-differences framework. Using publicly available trade data from 2015 through 2019, we regress the 12-month change in exports at the product-country level on product-specific variation in import tariff exposure measures while controlling for potential foreign retaliatory tariffs that those exports may have faced. We estimate a differential in growth rates in high relative to low exposure products (first difference) in the period before and after the waves of new import tariffs (second difference). ${ }^{6}$

We find that average bilateral export growth at the country-product level was lower in products with a higher share of exporters subject to import tariff increases. We further trace out the timing of these effects by interacting the import tariff exposure measure with quarterly indicators. We find that exposure depresses export growth in 2018 and especially 2019. Exported products with average exposure had a growth rate of about 0.75 log points lower than an unaffected products in 2018 and about $1.3 \log$ points lower in 2019. By 2019, this magnitude is equivalent to an ad valorem tariff on U.S. exports of almost $1.5 \%$ for the average country-product export. For sectors with exposure two standard deviations above

\footnotetext{
${ }^{5}$ The top 1 percent of U.S. traders account for more than 80 percent of total U.S. trade (Bernard, Jensen, Redding and Schott, 2018).

${ }^{6}$ We measure exposure at the HS 6-digit product level, which is the most dis-aggregated product code that is consistent across countries and time. The retaliatory export tariff data is linked to U.S. export flows at the the HS 6-digit product level.
} 
the mean, depending on which yearly effects are used, this implied ad valorem equivalent tariff is $3-4 \%$, close to the average, statutory MFN tariff rates imposed on trade partners by the U.S. and E.U.

This paper makes three main contributions. First, to our knowledge we are the only paper to use linked U.S. firm-trade transactions data to assess the incidence of the 20182019 tariffs on firms, jobs, sectors, and export growth using aggregated measures of firms' supply chain networks. We thus broaden our understanding of the impacts of the 2018-2019 tit-for-tat tariff wars in an era of outsourcing and global production fragmentation. Our contribution is complementary to several recent papers that study the incidence of the 20182019 tariffs. $^{7}$ Flaaen, Hortaçsu and Tintlenot (2020) estimate that tariff increases caused washing machine prices to rise by 12 percent. Amiti, Redding and Weinstein (2019) and Fajgelbaum, Goldberg, Kennedy and Khandelwal (2020) study the direct impacts of the 2018-2019 U.S. import tariff increases on U.S. import prices and the direct impact of the foreign retaliatory tariff increases on U.S. export prices. Cavallo, Gopinath, Neiman and Tang (2019) also examine the passthrough of U.S. import tariff increases to U.S. importers and retailers using firm-level data. However, these studies do not consider spillover effects of increases in U.S. import tariffs on U.S. exports through supply chains. ${ }^{8}$ Our estimates suggest accounting for supply chain linkages would likely increase the welfare costs of the 2018-2019 U.S. tariff increases.

Second, our results demonstrate that firms' reliance on global supply chains can complicate the application of traditional mercantilism - trade policy that aims to improve the balance of trade by reducing imports and promoting exports. In a counterfactual exercise, we find the reduction in export growth would have been attenuated by $35 \%$ if the tariffed products were not part of tightly linked supply chains. Blanchard, Bown and Johnson (2016) show that global supply chains, which increase the foreign content embodied in domestic final goods, should lower a government's incentive to impose tariffs on inputs. Our results provide empirical motivation for that incentive, but highlight how designing the optimal tar-

\footnotetext{
${ }^{7}$ Several papers have examined non-trade outcomes. Waugh (2019) studies the impact of Chinese retaliatory tariffs in 2018 on U.S. consumption to find that counties more exposed to Chinese tariffs experienced 2.5 percentage points lower growth in auto sales compared to counties with lower exposure. Blanchard, Bown and Chor (2019) study the impact of a county's exposure to U.S.-imposed import tariffs and foreign retaliatory export tariffs on the county's Republican vote share in the 2018 U.S. House elections. Flaaen and Pierce (2019), using aggregated input-output tables, examine the effect of higher input costs from the 2018-2019 U.S. import tariffs on domestic output and employment in the U.S. manufacturing sector; while Bown, Conconi, Erbahar and Trimarchi (2020) carry out a similar analysis but consider the supply chain effects of anti-dumping duties.

${ }^{8}$ An exception is Benguria and Saffie (2019) who study the impact of tariffs and uncertainty on U.S. exports. However, the authors use aggregated input-output tables to measure input tariffs.
} 
iff policy may be difficult in practice. For example, the first phase of import tariff increases on Chinese products under Section 301 were intended to target specific Chinese products where U.S. consumers and businesses had alternative country sourcing options (U.S. Senate Committee on Finance, 2018). But our findings suggest that firms were unable, at least in the short-term, to reorient sourcing strategies, perhaps because buyer-seller relationships embody relationship specific investments and capital cannot easily be replaced by alternative foreign and domestic sourcing. ${ }^{9}$

Finally, we make a novel methodological contribution. Confidential firm-transaction linked data is available with much longer processing lags (typically two years or more in the U.S.) that prohibits contemporaneous analyses of firm-level impacts of the 2018-2019 tariffs. But the trading status of large firms is persistent. Moreover, even if individual firms enter and exit international markets, population moments constructed from the cross-section of firm-level data should be representative of the firm trade participation at an industry level, which provides a sufficient basis for constructing our import tariff exposure measure capturing supply chain linkages. We show that nearly contemporaneous, public-use monthly trade data can be combined with data moments derived from the rich, underlying detail in firm-level micro data to evaluate policy changes. Our approach could be extended to better inform the policy making process in international trade and other economic applications.

The rest of the paper is organized as follows. Section 2 describes our data sources and provides summary statistics on U.S. importers facing import tariffs and U.S. exporters facing retaliatory foreign export tariffs. We describe the empirical approach in Section 3 and present the results in Section 4. Section 5 concludes.

\section{Measuring the Impact of Tariffs with Firm Data}

We link confidential micro data on U.S. trading firms to publicly available lists of product codes subject to newly imposed import and export tariffs. Thus, we can determine which firms are being directly affected by import and export tariffs. We combine information on the value, quantity, and HS product code traded by firms as well with their employment, number of establishments, age, and sector of operation.

\footnotetext{
${ }^{9}$ The cost of switching suppliers may be very high as demonstrated by Monarch (2016) in the context of buyer-supplier relationships in U.S.-China trade.
} 


\subsection{Timing and Characteristics of New Tariffs}

We construct a database of monthly U.S. import tariffs at the HS 8-digit level from publicly available tariff schedules published by the U.S. International Trade Commission. For all tariff increases since the beginning of 2018 through 2019, we keep track of the HS code, the new tariff rate, and the date of the change. ${ }^{10}$

Multiple lists of tariff lines were circulated weeks or more in advance of implementation. In the case of China, the lists were often modified on the date of implementation and products added or dropped in subsequent Federal Register notices. The lists of new import tariffs are so broad that some tariffed products are not even imported by the U.S. from China or any other country. However, for every newly tariffed country-product pair that is traded, there must be at least one firm facing a potential supply chain disruption or some form of higher costs, e.g. actual duties paid, a new sourcing decision, or even lobbying for exemptions.

The scope and timing of the import tariffs is show in Figure 2. We match the new tariff lines, at the HS 8-digit level, by date in 2018-2019 to country-product level annual import totals in 2016. ${ }^{11}$ Over 10,000 country-product pairs, more than half coming from China, are ultimately affected. Firms may import multiple affected products and products may be imported across multiple sectors such as manufacturing, services, or retail. Moreover, many of the tariff waves and escalations were threatened, then modified or delayed (sometimes indefinitely) before the precise implementation date shown on the graph. The uncertainty about timing of implementation, the duration of the tariffs, and which products would be on the final lists may have been an additional source of disruption to firms.

An important feature of the tariff increases was that they fell mainly on intermediate goods. For all affected products, the tariff increased by an average of about 24 percentage points over 2018-2019. Intermediate goods represent $56.8 \%$ of the total value of goods receiving tariffs, compared to $27.3 \%$ for capital and $15.6 \%$ for consumption goods. ${ }^{12}$ This is especially salient in the case of tariffs against Chinese imports. Under the Section 301 tariffs, $82 \%$ of all intermediate goods imported from China had received tariffs by May 2019 (Bown, 2019). In comparison, the share of new tariffs on capital and final goods sourced from China were only $38 \%$ and $29 \%$, respectively.

U.S. tariff increases on different countries and products were often followed by retaliation against U.S. exporters. For this reason, we also construct a database of retaliatory foreign

\footnotetext{
${ }^{10}$ Fajgelbaum, Goldberg, Kennedy and Khandelwal (2020) have a summary of the timeline of the waves of tariff increases and affected products. See Appendix A for more details on the tariff lists in our data.

${ }^{11}$ We use 2016 as a base year to match our firm-trade transactions data linkage below.

${ }^{12}$ These are value value-weighted tariff increases and trade shares using 2017 annual import data. We use the United Nation's Broad Economic Classification to classify goods.
} 
export tariffs at the 6-digit HS (HS6) level using the timeline from Bown and Zhang (2019). The trade-weighted average tariff increase from retaliation is about 20 percentage points and affects around $8 \%$ of total U.S. exports. ${ }^{13}$ The average change in exports for all countries and products is effectively zero. But for affected export products, the average annual change over 2018-2019 is about $13 \mathrm{log}$ points in our regression sample (see Appendix Table A-2). Nevertheless, as show in Figure 1, foreign retaliation alone does not explain a slowdown in U.S. export growth during this period.

We summarize these features at the firm-level in the next section before turning to our estimation strategy.

\subsection{Firm-Level Trade and Employment Data}

We draw U.S. firm-level trade and employment characteristics from two sources of confidential microdata covering the universe of merchandise trade transactions and non-farm, private sector employers.

The Longitudinal Firm Trade Transactions Database (LFTTD) contains transactionlevel detail on the universe of imported shipments valued over US $\$ 2,000$ and exported shipments valued over US\$2,500 of merchandise goods. Using the 2016 LFTTD, we identify U.S. exporters and importers and link the firms directly to the U.S. import tariff and foreign retaliatory export tariffs imposed in 2018-2019 at the country-HS6 product-month level.

We construct the import tariff exposure measure using 2016 trade data for two reasons. First, it minimizes concerns that our measure may be contaminated by any anticipatory or policy uncertainty induced factors influencing firms' decisions in advance of tariffs actually being imposed. Using 2016 predates the outcomes of the U.S. presidential election for most of that year or any anticipatory affects in 2017. Second, contemporaneous exposure measures may reflect endogenous firm-level responses to the trade policy changes. These include exit from sourcing in some foreign markets and entry into others induced by the policy change.

We use the 2016 LFTTD to describe the firm-level incidence of the 2018-2019 tariff increases because importing and exporting are very persistent activities. Firms we identify as being affected by the tariffs using 2016 data are very likely to be affected in the years tariffs are actually imposed. The implication is that the cross-section, population level statistics of 2016 firm characteristics should be representative at the aggregate and industry-aggregate level of import and export exposure to future tariffs, even if firms responded to the policy

\footnotetext{
${ }^{13}$ Figures calculated using 2017 trade weights and exclude retaliation after the September 1, 2019 U.S. tariff increases. Additional details in Appendix A.
} 
change in 2018, for instance, by terminating imports from a source country. As a robustness check, we also augment our exposure measures with data from the 2014 and 2015 LFTTD.

We match trading firms in the LFTTD to the Longitudinal Business Database (LBD). The LBD tracks all U.S. establishments in the non-farm, private sector employer universe over time (Jarmin and Miranda, 2002). ${ }^{14}$ It contains information on every establishment's firm affiliation, year of birth (used to construct firm age), industrial activity at the six-digit NAICS level, employment, and payroll.

\subsection{Characteristics of Affected Importers and Exporters}

Table 1 presents a broad picture of how U.S. importers and exporters, as identified in 2016, were affected by the 2018-2019 tariffs. Taking all of the newly imposed U.S. tariffs in 2018 through 2019, affected imports represented $11.2 \%$ of total imports (about $\$ 247$ billion) and almost a third of all importing firms. The affected firms employed $32 \%$ of all U.S. nonfarm private sector workers. For the average affected importer, $46.5 \%$ of their import value was subject to import tariff increases. In the aggregate, all of the newly imposed foreign retaliatory export tariffs in 2018 through 2019, affected 8\% of U.S. exports in LFTTD (about $\$ 115$ billion) and $18.7 \%$ of all exporting firms. These exporting firms employed about $23 \%$ of all non-farm private sector employees. ${ }^{15}$ For the average affected exporter, about one third of their export value was subject to foreign retaliatory tariff increases.

Panel A in Table 2 presents characteristics of firms importing products in 2016 that would face U.S. import tariff increases in the 2018-2019 period. The average importing firm facing tariffs was about twice as large as the average importer, both in terms of employment (430 vs. 212 workers) and the number of establishments (9 vs. 5). Comparing the last two columns illustrates the well-known fact that importers exhibit a significant size premium relative to the average firm and indicates that U.S. import tariffs overwhelmingly impacted the largest firms in the U.S. economy. The age profile of affected importers is very similar to all importers; and the typical annual pay for workers at firms facing import tariffs is also comparable, about $\$ 58,000$ per worker.

We carry out a similar breakdown for U.S. firms facing retaliatory tariffs from foreign countries in Panel B of Table 2. Affected exporters were two to three times as large as the average exporter, using employment or the number of establishments. Retaliatory tariffs fell

\footnotetext{
${ }^{14}$ LBD excludes operations with no statutory employees, e.g. self-employed, farms (but not agri-business), and the public sector. At the time of this study, the most recent available year of the LBD is 2016 .

${ }^{15}$ Since many firms both import and export, this share is not mutually exclusive from the share of workers affected by import tariffs.
} 
on some of the largest firms in the U.S. economy. The impacted exporters exhibited higher average earnings and were also older compared to the average exporter.

\subsection{Characteristics of Affected Sectors}

Linking the trade data to firm-level characteristics also enables an examination of the most affected sectors. We identify which firms in 2016 are trading products that face tariff increases in 2018-2019 and aggregate up to broad sectors using firm industry and employment information.

We report summary statistics, in Table 3, on the share of workers impacted by the increase in U.S. tariffs and average duties paid per worker overall and across four broad sectors: manufacturing, wholesale, retail, and other. ${ }^{16}$ In some of the sectors most affected by U.S. import tariffs, such as manufacturing and retail, upwards of $60 \%$ of workers are employed at firms facing tariff increases. This is in contrast to sectors included in "Other" where relatively few workers are employed at affected firms, including firms providing services or agricultural operations. ${ }^{17}$ In the second column, we observe similar sectoral rankings in the share of workers that were most exposed to increases in foreign retaliatory export tariffs.

The third column of Table 3 shows the implied average duty per worker by sector. This measures the total tariff bill of all affected firms in a sector divided by the number of workers in that sector. ${ }^{18}$ To the extent that these imputed tariffs can be interpreted as a direct increase in costs, manufacturing firms potentially paid about $\$ 1,600$ in tariffs for each worker, while wholesale firms paid closer to $\$ 5,000$ per worker. ${ }^{19}$ The typical affected firm in the economy paid about $\$ 900$ per worker in tariffs. Using payroll (earnings) per worker from Table 2 , the implied duties were equivalent to $1.5 \%$ of the average wage bill.

\footnotetext{
${ }^{16}$ Manufacturing is defined as all sectors within NAICS 31-33; Wholesale is defined as all sectors within NAICS 42; Retail is defined as all sectors within NAICS 44 and 45; and Other includes all other sectors except 92 (Public Administration).

${ }^{17}$ Some reports indicate that individual farmers may be negatively affected by new tariffs (see Bunge et al. (2019), for example), but the the LBD only covers non-farm sectors.

${ }^{18}$ Total tariffs paid are imputed based on total imported value of tariffed products in 2016 times the respective tariff increase as of April 2019. The calculation assumes that the import tariff burden is borne as an additional cost for U.S. firms. Conditional on maintaining import volumes at 2016 levels, the implied values are consistent with evidence of complete passthrough of the tariffs to U.S. firms (Amiti, Redding and Weinstein, 2019; Fajgelbaum, Goldberg, Kennedy and Khandelwal, 2020; Cavallo, Gopinath, Neiman and Tang, 2019).

${ }^{19}$ Although a large fraction of retail workers were employed at affected firms, the overall per-worker burden on these firms was fairly small because tariffs fell mainly on imported intermediates rather than consumer goods.
} 


\subsection{Import Tariffs and U.S. Exporters}

The broad coverage of intermediate goods subject to the 2018 and early 2019 import tariffs means that firm-level supply chains were more likely to be directly affected relative to consumer products. The official Federal Register notice of tariff increases in April 2018 indicates that tariffed products were chosen by "selecting products [...] with lower consumer impact" (Federal Register, April 6, 2018).

Linking import and export activity at the firm level reveals the extent to which supply chains were potentially impacted. We consider three distinct definitions of exposure to import tariff increases. We begin by defining exporters to be affected if they face new import tariffs on any product, capturing an overall increase in input costs at the firm level. Under this measure, $84 \%$ of total U.S. exports were by firms facing import tariff increase on at least one product. The share of affected firms is smaller, 24\%, but these exporters tend to be larger than average. However, all exports of an affected firm may not be impacted by import tariff increases, especially if the affected products are a small share of an exporter's import basket.

Another approach is to consider whether a firm's exported products are in the same broad product category as its imported products facing new import tariffs. To operationalize this, we define exporters to be affected only if they face new import tariffs in a HS6 product within the same 4-digit HS (HS4) chapter as their exports. Using this approach, $43 \%$ of U.S. exports are subject to the new import tariffs within related product groups, representing $13 \%$ of all U.S. exporters. Finally, we make the connection between the tariffed imports and exports of the firm even tighter by defining exporters to be affected only if they face new import tariffs in the same HS6 product as their exports. Under this definition, close to one-third of U.S. exports and $10 \%$ of U.S. exporters are potentially affected by U.S. import tariffs. Table A-1 includes a complete summary of these measures.

Imports of products in the same product groups as a firm's exported products should more closely measure supply chain linkages due to foreign sourcing or offshoring. ${ }^{20}$ The main idea is that closer the inputs are to the final output product classification, the more likely it is that the U.S. firm could have produced these inputs. Our approach relates directly to the Hummels, Jørgensen, Munch and Xiang (2014) measure of firm-level offshoring as imports of products in the same HS4 heading as the firm's output. This is our "baseline" definition to identify supply chain linkages. Bernard, Fort, Smeets and Warzynski (2020) measure firm-level offshoring as imports of products in the same HS6 category as the firm's output,

\footnotetext{
${ }^{20}$ Hummels, Munch and Xiang (2018) define three elements of offshoring: (i) intermediate inputs used for production; (ii) imported inputs; and (iii) inputs that could have been produced internally within the same firm.
} 
which we will call a "narrow" definition of supply-chain linkages, while we will refer to the measure capturing all exports by firms facing any import tariffs as "broad". We establish the robustness of our results using all three definitions. We also provide empirical tests of the strength of the supply-chain linkages implied by each definition.

\section{Empirical Framework}

We construct product-level, population statistics on exposure to increases in import tariffs by U.S. exporters. We first describe the measures and then aggregate up from the firm-level to various product-level exposure statistics. We then use these product-level measures to estimate the impact on export growth at the country-product level.

\subsection{Import Tariff Exposure}

We begin by constructing product exposure measures from the cross-section of 2016 exporters. We show that the measures share useful aggregation properties and are related to differential trends in U.S. export growth across the most exposed and all other product groups.

We construct measures of exposure by 6-digit HS product codes. ${ }^{21}$ First, we count the number of unique exporters in each HS6 product, $p$, regardless of their import participation. Second, we count the subset of these exporters that are importing a product subject to import tariff increases in 2018-2019. In our preferred measure, we use the 4-digit heading, HS4, to define the set of imports that are part of a firm's export supply chain. ${ }^{22}$ Let $H$ be the set of exported products in a HS4 heading. For each exported HS6 product $p \in H$, we count the total number of exporters in 2016 that import at least one tariffed product in $H$.

The share of exporters hit by an import tariff in the same HS4 category as their exports forms our baseline measure of import tariff exposure $\left(I T E_{p}\right)$,

$$
I T E_{p}=\frac{\text { Exporter } N u m_{p, 2016}^{T, \text { SameHS4}}}{\text { Exporter Num }}{ }_{p, 2016} .
$$

\footnotetext{
${ }^{21}$ This is not the finest level of detail, but we use HS6 codes because they can be consistently concorded over time for imports and exports and matched to export tariff retaliation reported at the same level. We check the robustness of our results, in Table 15, to a major revision to the Harmonized System nomenclature in 2017 that affected hundreds of 6-digit codes. See Appendix A for details on constructing the concorded export flows.

${ }^{22}$ There are about 1,000 HS4 product codes.
} 
The numerator, Exporter Nump, $\mathrm{m}_{p, 2016}^{T, S a m e H S}$, is the total number of exporters in 2016 selling HS6 product $p$ that are hit by new import tariffs in their supply chain. The denominator, Exporter Num $_{p, 2016}$, is the total number of exporters selling HS6 product $p$ in 2016. This measure captures supply chain linkages due to the similarity of exported and imported products. ${ }^{23}$ Appendix B lays out a conceptual model of how this measure is consistent with accounting for heterogeneous effects of the tariffs on firm output across firms of different sizes and productivity.

We also construct two additional exposure measures: a broad and a narrow measure of import tariff exposure. The broad measure counts an exporting firm as exposed if any of its 2016 imported products are subject to new tariffs in 2018-2019. Specifically,

$$
I T E_{p}^{\text {Broad }}=\frac{\text { Exporter } N u m_{p, 2016}^{T, A l l}}{\text { Exporter } N u m_{p, 2016}}
$$

where ExporterNum ${ }_{p, 2016}^{T, A l l}$ is the total number of exporters in 2016 selling a HS6 product $p$ with at least one of its imported product categories subject to tariff increases in 20182019. The denominator is the same as in equation (1). Thus, IT $E_{p}^{\text {Broad }}$ measures the overall exposure of exporters of a HS6 product to U.S. import tariffs.

The narrow measure of import tariff exposure, in contrast, measures exposure as imports of tariffed products in the exact same HS6 product as the firm's exports. This is defined as,

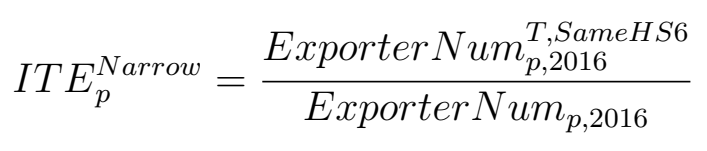

where Exporter $N u m_{p, 2016}^{T, S a m e H S 6}$ measures the total number of exporters in 2016 selling a HS6 product $p$ that also import products in $p$ subject to tariff increases in 2018-2019. This is more restrictive than the baseline measure and may capture very tightly linked products in a firm's supply chain.

An important property of all three measures is that they share the same denominator and the numerators are nested subsets. That is, for any HS6 product $p$, we know exposure measures must satisfy the inequality

$$
I T E_{p}^{\text {Narrow }} \leq I T E_{p} \leq I T E_{p}^{\text {Broad }}
$$

\footnotetext{
${ }^{23}$ By constructing the import tariff exposure measure at the level of the exported product $p$ rather than at the product-country level, we assume that the firm's production function is product- and not countryproduct specific. Our exposure measure captures the supply chain frictions specific to inputs for a particular output that is not necessarily different across buyers.
} 
We leverage this property to examine whether the strength of linkages within the supply chain, which is increasing in the narrowness of the measure, is more or less important to explain weaker export growth.

To illuminate our approach, consider three hypothetical firms that produce aluminum articles under HS4 Heading 76.10, "Other Articles of Aluminum," in the U.S. Schedule B export codes. This heading includes ladders, Venetian blinds, luggage frames, and the sub-heading 76.16.10: "aluminum fasteners" such as screws, bolts, rivets, cotter pins, etc. In September of 2018, Chinese imports of fasteners under 76.16 .10 were tariffed at $10 \%$ (and later 25\% in May of 2019). First, for some firm X, the tariffed fasteners may have been simple, standardized screws and bolts for which potentially more costly alternatives were available from other domestic or foreign sources. But even if an alternative supplier were found, the new tariffs would have induced a costly search, required new logistics, and possibly entailed new contracting frictions. Second, for some other firm Y, the situation could be more complex; the fasteners may have been highly specialized, proprietary screws used in the manufacture of its final goods. Replacement suppliers might be hard to find or difficult to integrate into firm Y's existing supply chain. Lastly, while we do not explicitly measure the upstreamness or downstreamness of the import tariff exposure, it is possible that a third U.S. firm Z exports intermediate inputs to Asia, e.g. articles of aluminum, which are eventually finished or assembled in China. If those products are then exported back to the United States, this exposes firm Z to the new U.S. tariffs downstream in its production process under the same HS4 heading. Our goal is to estimate effects of import tariff exposure effects on exports, therefore, we need not take a stand on whether the U.S. exporter is upstream (Firm X and Y) or downstream (Firm Z) in the supply chain.

The above examples illustrate that the HS nomenclature is not descriptive enough to determine the specificity of any particular imported input across firms or its production stage in the supply chain. Thus, we aim to estimate the average effect by aggregating up to the share of affected firms that export an HS6 product and pay tariffs on some product in the same HS4 heading. If the typical firm can easily switch suppliers or even produce the tariffed import on its own, that would be reflected in small or insignificant effects in our ultimate regression analysis in which we control for a variety of country- and industry-level supply and demand shifters. In our baseline results and robustness checks to follow, the evidence is consistent with spillovers throughout the supply chain.

Using a count-based share at the product $p$ level - instead of a value-based share - better captures exposure for typical firms. There are several sources of potential measurement error from using an exposure measure weighted by the share of export value in 2016 affected by tariffs in 2018-2019. First, value weighting could place undue influence to only a few 
firms in the 2016 firm-level data, some of which may be extreme outliers. Second, a firm's idiosyncratic response to the trade friction need not be proportional to its export value, i.e. firms with lower export values may be more affected by import tariffs and vice versa. Third, a firm's export value can be more susceptible to yearly fluctuations even if export participation is stable. Relying on export value in a single year to weight future exposure could thus potentially diminish or magnify supply chain frictions. ${ }^{24}$

Table 4 provides summary statistics, means and standard deviations in parentheses, of all our exposure measures using the three different definitions of supply-chain linkages. The first column considers the broad, the second column the baseline, and the third column the narrow definitions.

The first row focuses on the measures constructed using 2016 LFTTD and used in our main empirical analyses. The $I T E_{p}^{\text {Broad }}$ measure has a mean of 0.55 ; the $I T E_{p}$ measure has a much smaller mean of 0.11 ; and the $I T E_{p}^{\text {Narrow }}$ measure has the smallest mean of 0.05. Under the baseline definition, for the average HS6 exported product, $11 \%$ of exporters import products that both (a) face import tariff increases in 2018-2019 and (b) are in the same HS4 category as that exported product.

The second row displays the same set of statistics but constructed using data from LFTTD averaged across 2014-2016. These average measures are used in robustness exercises. We find that the average values for each exposure measure are similar to only using 2016 data.

The last three rows decompose the import tariff exposures by tranches of tariffs over 2018-2019, which we consolidate into 3 groups relative to Figure 2. The first tranche of tariffs (T1) were imposed on solar products and washing machines beginning in January 2018. The second tranche of tariffs (T2) were imposed on steel and aluminum products beginning in March 2018. The final tranche of tariffs (T3) were imposed on a variety of goods originating in China in three waves, beginning in June 2018. Consistent with the overall value of imports facing tariffs, we can see that the average values of exposure for all definitions are highest for tariffed goods originating in China (T3); followed by aluminum and steel tariffs (T2); and lowest for solar products and washing machine tariffs (T1).

The most and least exposed products according to our baseline measure are consistent with the emphasis on intermediate inputs and metals. Table 5 lists the five most exposed 2-digit HS Chapters; four of them are export products related either to machinery (HS Chapters 84 and 85) or metals (HS Chapters 72 and 73). We measure exposure of an HS2 sector by taking the share of HS6 products in each HS2 with an IT $E_{p}$ greater than the 75 th

\footnotetext{
${ }^{24}$ We refer the reader to Appendix B for more detail on these issues.
} 
percentile of the distribution (i.e. chapters with a large number of highly exposed products). ${ }^{25}$ These five most exposed HS chapters represent about a third of U.S. exports in 2016. At the same time, a glance at the least exposed exports suggests they are not typical or significant importers of intermediate inputs - the bottom panel of Table 5 includes products such as feathers and artificial hair, vegetable materials, minerals, wood pulp, and animal fodder.

To motivate our exposure measure further with public-use data, we provide simple, nonparametric evidence of differential export growth rates between exposed and all other 2-digit products. For each group (most exposed vs. all other exports) we aggregate export values by country and month from 2015 to 2019. We then construct the cumulative export growth rates from 2015 to 2019 on a rolling basis. ${ }^{26}$ We plot the local linear polynomial through a balanced sample for each group centered on its mean in Figure 3 for each month from 2016 to 2019. The growth rates of the most exposed vs all other HS2 products are similar until mid-2018. Export growth rates diverge shortly after the initiation of trade hostilities and widen throughout 2019. ${ }^{27}$

We turn next to estimating the differential effects at the detailed country-HS6 product level where we make full use of our continuous $I T E_{p}$ measure and control for foreign retaliatory tariffs and a variety of confounding variables using high dimensional fixed effects.

\subsection{Estimating Equation}

Our empirical approach combines product level import tariff exposure measures with publicuse data on monthly U.S. exports at the country-HS6 product level. Our outcome of interest is export growth. We begin with the premise that trade has a standard gravity form and we can decompose bilateral exports (in $\operatorname{logs}$ ) into fixed effects for destination $c$, product $p$, time $t$, and other frictions as follows,

$$
\ln \text { Exports }_{p c t}=\theta_{\tau} \ln \left(1+\tau_{p c t}\right)+\gamma_{t} I T E_{p}+\alpha_{c}+\alpha_{p}+\alpha_{t}+\epsilon_{p c t}
$$

where $\ln$ Exports $_{p c t}$ is $\log$ value of exports for a product $p$ to country $c$ in month $t$. Tariffs, $\ln \left(1+\tau_{p c t}\right)$, are the ad valorem equivalent foreign retaliatory export tariffs and $I T E_{p}$

\footnotetext{
${ }^{25}$ This summary statistic mirrors our regression framework at the HS6 level.

${ }^{26}$ Specifically, we compute log changes by country and exposure group from January 2016 to January 2015 and January 2017 to January 2015 and so forth for each country and month. We residualize the data relative to its mean by the panel identifier: country by exposure group by calendar month.

${ }^{27} \mathrm{We}$ confirm the statistically significant difference from 2018 forward in unreported regressions that include a treatment indicator for the exposure group in 2018 and 2019, panel ID fixed effects (country by exposure group by calendar month) and country-time fixed effects with standard errors clustered on the panel ID.
} 
measures disruptions to supply chains via exposure to increased import tariffs as defined in Equation (1). The $\alpha_{x}$ terms are fixed effects for country, product, and time. The inclusion of $I T E_{p}$ as a regressor in the export equation is consistent with the aggregation of unobserved firm-level export responses to import tariffs over several rounds of tariff implementation. ${ }^{28}$

To handle seasonality in high frequency monthly trade flows, we take log differences of equation (4) relative to the same month in the previous year to obtain

$$
\Delta \ln \text { Exports }_{p c t}=\theta_{\tau} \Delta \ln \left(1+\tau_{p c t}\right)+\Delta \gamma_{t} I T E_{p}+\alpha_{c t}+\varepsilon_{p c t}
$$

where we combine country-time effects $\alpha_{c t}$. To the extent supply chain linkages reduce export growth, we predict that $\Delta \gamma_{t}<0$.

The 2018-2019 tariff increases on U.S. imports provides a quasi-natural experiment for evaluating the supply-chain effects on U.S. exports. The import tariff increases were largely unanticipated. The outcome of the 2016 U.S. presidential election was a surprise to most observers making it unlikely that affected industries could have anticipated the tariff changes. ${ }^{29}$ Our exposure measure is fixed by product and time using moments from firm-level trade flows in 2016 and should not be influenced by the 2016 presidential election or anticipation of tariffs in 2017.

Our approach aims to estimate the supply chain impact after the tariff escalation begins relative to the period before the tariff escalation. Thus, we interact $I T E_{p}$ with an indicator for post-2017 trade flows, $I(>2017 Q 4)$. Our estimation strategy is then a generalized difference-in-differences equation. We estimate whether export growth in industries with higher exposure to import tariffs, the first difference, is lower in 2018-2019 relative to 20162017, the second difference. Our estimation equation is

$$
\Delta \ln \text { Exports }_{p c t}=\theta_{\tau} \Delta \ln \left(1+\tau_{p c t}\right)+\left[\Gamma_{1}-\Gamma_{0}\right] I T E_{p} \times I(>2017 Q 4)+\Gamma_{0} I T E_{p}+\alpha_{c t}+\varepsilon_{p c t}
$$

where we denote pre-period average of coefficients with subscript 0 and post-period with subscript 1. Thus $\Gamma_{0}=\overline{\Delta \gamma}_{t}$ for $t \leq 2017 Q 4$ and $\Gamma_{1}=\overline{\Delta \gamma}_{t}$ for $t>2017 Q 4$.

The coefficient on the non-interacted version of $I T E_{p}, \Gamma_{0}$, can be thought of as the effect of future tariff exposure on pre-tariff export growth. For example, this may capture

\footnotetext{
${ }^{28}$ We outline a simple empirical model in Appendix B showing how these responses can be aggregated up to a time-varying export attenuation factor. We show that the time-varying export attenuation, if any, is estimated by the coefficient on $I T E_{p}$, or $\gamma_{t}<0$.

${ }^{29}$ Our public-use data exercise in Figure 3 suggests parallel trends in the months prior to the trade war. Fajgelbaum, Goldberg, Kennedy and Khandelwal (2020) also show there is no evidence of differential preexisting trends in U.S. exports and imports in an event study framework.
} 
the effect of overall supply chain sensitivity of export growth in the period before the tariffs were imposed. This effect is also likely to be correlated with other unobserved product characteristics that influenced export growth. In our baseline regressions, therefore, we include product-level $\alpha_{p}$ fixed effects. We can then identify only the difference $\left[\Gamma_{1}-\Gamma_{0}\right]$, which is negative if $\Gamma_{1}<\Gamma_{0}$ such that export growth is lower in the post-period when tariffs are in effect.

In an extended version of the estimating equation, we include several additional sets of fixed effects and write the coefficients and indicators more parsimoniously, as follows:

$$
\Delta \ln \text { Exports }_{p c t}=\theta_{\tau} \Delta \ln \left(1+\tau_{p c t}\right)+\Gamma_{Q_{t}-0} I T E_{p} \times Q_{t}+\alpha_{c t}+\alpha_{p q}+\alpha_{I c}+\alpha_{I t}+\varepsilon_{c p t} .
$$

This flexible specification allows us to estimate separate difference-in-differences coefficients on import tariff exposure for each $Q_{t}$ indicator, which equals one in each quarter from 2018Q1-2019Q4 and zero in 2016Q1-2017Q4. So the coefficient $\Gamma_{Q_{t}-0}=\left[\overline{\Delta \gamma}_{t \in Q_{t}}-\overline{\Delta \gamma}_{0}\right]$ and the $Q_{t}-0$ subscript is shorthand for the effect in $Q_{t}$ relative to the omitted group before tariffs were implemented: monthly export growth in 2016 and 2017. The underlying identifying variation is all country-product exports in the same product $p$ during the three months included in quarter $Q_{t}$. The estimated time-variation in $\Gamma_{Q_{t}-0}=\left[\overline{\Delta \gamma}_{t \in Q_{t}}-\overline{\Delta \gamma}_{0}\right]$ reflects several characteristics of import tariffs from 2018-2019. First, they are implemented against different countries and products over a period of time. Second, it may take several months for exporters hit by import tariffs to adjust their export behaviors.

We control for destination-time unobservable factors (e.g. exchange rate fluctuations, time-varying aggregate trade barriers, and destination-specific demand shocks) by including $\alpha_{c t}$ fixed effects. In all regressions we include HS6- "calendar quarter" fixed effects, $\alpha_{p q}$, that control for other U.S. supply-side growth trends and other unobservable HS6 product shocks. ${ }^{30}$ This set of fixed effects means that $\Gamma_{0}$ is not identified separately. We also include sector $\times$ country and sector $\times$ time fixed effects in all specifications, where a sector is one of 21 "sections" - a grouping of similar HS2 categories. ${ }^{31}$ The sector $\times$ time fixed effects control for shocks to export supply or import demand. We stack rolling, twelve-month changes in U.S. exports in 2016-2019. Since we include HS6-calendar quarter fixed effects, the omitted pretariff comparison period is monthly export changes in 2016 and 2017 from the same calendar quarter. Standard errors are clustered at the HS6 level, which is the level of variation for the ITE measure.

\footnotetext{
${ }^{30}$ Calendar quarter, $q$, refers to Q1, Q2, Q3, or Q4.

${ }^{31}$ The official list of sections published by World Customs Organization (2019).
} 


\section{Results}

We estimate a set of baseline results that are robust to variations in the specification and measures of exposure. We also present impacts of import tariff exposure in the pre-tariff escalation period only.

\subsection{Baseline Results}

In Table 6 , we present coefficient estimates of the interaction between $I T E_{p}$ with an indicator for post-2017Q4 time periods as in Equation (6) to estimate the average effect on export growth during the tariff escalation relative to the pre-tariff periods. We successively add fixed effects across the columns. All specifications include HS6-calendar quarter fixed effects.

We find a negative and statistically significant coefficient on the interaction term between $I T E_{p}$ and the post-2017Q4 indicator across all columns. Products more exposed to U.S. import tariff increases experienced lower export growth relative to less exposed products in the post-tariff period, compared to the same difference in the pre-tariff period. Results from the most demanding specification including HS6-calendar quarter, country-time, countrysector, and sector-time fixed effects in Column (3), reveal that a one standard deviation increase in the tariff exposure measure, ITE $E_{p}$, lowers U.S. export growth by about $1 \log$ point for the typical affected sector. The mean value for the $I T E_{p}$ measure is 0.11 with a standard deviation of 0.11 . Thus, the coefficient implies that a product at the mean of the $I T E_{p}$ distribution experiences about 1 log point lower export growth than a product with no affected exporters. ${ }^{32}$ The table also shows that a 1 log point increase in foreign retaliatory export tariffs, $\tau_{p c t}$, lowers U.S. export growth by about 0.9 log points, a result in line with Fajgelbaum et al. (2020).

Table 7 continues to use the saturated specification from Column (3) in Table 6 and contrasts the results across the baseline, broad and narrow measures. The coefficient magnitudes are consistent across specifications, and all three exposure measures point in the same direction: U.S. export growth was weakened by increases in U.S. import tariffs.

Next, we estimate the specification in Equation (5), but restricting the sample to a "placebo" pre-tariffs period, 2016-2017. The dependent variable is the 12-month change in HS6-country exports from January 2016 through December 2017. We define 2017 as the "post" period. In Table 8, we find a positive but statistically insignificant relationship between U.S. export growth in a product and its future import tariff exposure. Thus, the

\footnotetext{
${ }^{32}$ We calculate $(-0.092 \times 0.11) \times 100=1.01$.
} 
variation in our measure of exposure to import tariffs is only correlated with export declines once the tariffs are actually enacted, constituting further evidence of the importance of recent changes in trade policy.

\subsection{Tranche-Specific Results}

While the above results indicate that overall import tariff exposure dampened exports over 2018-2019, we can examine, separately, the role of each major tranches of new tariffs. We separate the import tariff exposure measures by the three main tariff episodes or tranches: solar products/washing machines (T1), steel/aluminum metals (T2), and pooling the China waves (T3).

In Table 9 we find each tariff tranche has a negative effect on export growth but of differing magnitudes. We focus on the baseline measure in column (1). Evaluating the coefficient at the mean exposure from Table 4 implies that for the solar and washing machine tariffs $(\mathrm{T} 1)$, the typical exposed product has lower export growth by about 0.07 log points $(=-0.702 \times 0.001 \times 100)$. The effect is larger for the typical exported sector affected by the March 2018 metals tariffs (T2), which have lower export growth by about 0.11 log points $(=-0.188 \times 0.006 \times 100)$ for the typical affected product. Finally, the impact is largest for a typical exposed product to China tariff waves (T3), which have about 0.73 log points $(=-0.070 \times 0.104 \times 100)$ lower export growth. ${ }^{33}$

The quantitative impact of import tariff exposure outside of Chinese imports is low, but responsiveness to shocks is broadly similar. To understand this, we need to normalize the coefficients for each tariff group relative to their variation in the data. Evaluating the impact of the different tranches at their mean values reflects that there are not as many firms in product categories facing import tariffs in T1 or T2 relative to T3 (see the means in Table 4). But we can compare the relative magnitude of the impacts of each of the three tranches in terms of changes in the China tariffs to infer how exposed product categories responded irrespective of the degree of exposure. Focusing on column (1), we transform the coefficients on T1 and T2 to a one standard deviation equivalent change in T3 tariffs by multiplying each coefficient by the standard deviation of the corresponding exposure measure and then normalizing by the standard deviation of the China (T3) exposure measure. The coefficient on T1 tariffs is normalized to -0.079 and T2 tariffs to -0.072 , both of which

\footnotetext{
${ }^{33}$ An exception the negative effects is T2 tariffs under the broad ITE measure in Column 2 . This may reflect large, multi-product firms that are disproportionately impacted by metal tariffs that import a variety of products outside the same HS4 chapter as their exports. In our robustness check for implementation timing in Table A-3 the same coefficient is positive, smaller, and no longer significant.
} 
are comparable in magnitude to the coefficient on the China tranche of $-0.070 .{ }^{34}$ So while firms facing metals tariffs may have a smaller impact on reduction in average export growth in this episode, the estimates suggest the export growth response to standardized shocks is similar across all the tariff tranches.

One potential issue with our approach above is that we ignore the timing of the tranches and interact each group with a pooled, post-2017 indicator throughout 2018-2019. We check that our results are robust to an alternative specification where we include import tariff exposure measures by tranche that take on a value of 0 prior to the date the first tariffs in that tranche go into effect and their continuous value thereafter. We find the results are largely unchanged as shown in Appendix Table A-3.

\subsection{Timing of Effects}

Although the first wave of the trade war began in January 2018 with the solar product tariffs, the majority of U.S. imposed import tariffs were not in place until late 2018, with another major ratcheting up of tariffs on imported intermediates from China occurring in May 2019.

We provide some decomposition of this timing in the variation across tranches discussed above in Table 9 (and Appendix Table A-3). However, many of the tariff waves were announced and threatened in advance, including detailed lists of tariff lines, as we discussed in Section 2. The latter may have induced some anticipatory effects, a chilling effect at the time of announcement or advancing import orders in advance of the increase. For this reason, we estimate the time variation in the supply chain impacts of changes in U.S. import tariffs directly by interacting quarter dummies with our ITE measures, as in specification (7). This allows the impact of $I T E_{p}$ to vary across quarters even though the $I T E_{p}$ measure itself is time invariant. We interact the import tariff exposure measure by specific quarters beginning in 2018.

Separating the timing out in more detail, there is strong evidence of significant, negative effects for the typical affected export product beginning in 2018Q3, as well as some signs of negative effects in earlier quarters depending on the exposure measure. In Table 10 the larger impacts in the latter part of 2019 are consistent with additional tariff tranches being added throughout 2018, and the tariffs from China being increased in early 2019. We expect a smaller initial effect in 2018 since our ITE measure uses all the newly-imposed tariffs through 2019, regardless of timing. Moreover, our results are consistent with exporters taking time to react due to existing inventories, adjustment costs, and uncertainty about how long the

\footnotetext{
${ }^{34} \mathrm{~T} 1:(-0.702 \times 0.012) / 0.107=-0.079$ and $\mathrm{T} 2:(-0.188 \times 0.041) / 0.107=-0.072$.
} 
tariff increases would remain in place. Interestingly, the effects for 2019 Q4 appear to be of smaller magnitude than earlier quarters, which reflects not only that suppliers may have started adjusting to the new tariffs, but also that the 12-month change in exports is beginning to include 2018 Q4, a period when export growth was already weakening significantly from import tariff exposure. ${ }^{35}$

The quantitative implications of these estimates are large, especially by 2019. We again consider a movement from unaffected to the mean value of the $I T E_{p}$ measure to assess the magnitude of these coefficients. In the worst quarter, 2019Q3, we estimate $\hat{\Gamma}_{2019 Q 3-0}=$ -0.185 . So the typical affected HS6 product has a 12-month change in exports that is about $2 \log$ points $(-0.185 \times 0.11 \approx-0.02)$ lower than the typical less affected product. Averaging the quarterly coefficients by year, i.e. -0.068 in 2018 and -0.116 in 2019, we find a reduction in export growth relative to unaffected products of almost $0.75 \log$ points in 2018 and 1.3 log points in 2019. Thus the two-year, cumulative change from summing the effects up is about 2 log points. These relative magnitudes are robust to all three exposure measures, as indicated in columns (2) and (3) for the narrow and broad measures, respectively. Regardless of the exposure measure, foreign retaliatory export tariffs had a large and negative impact on U.S. export growth.

To put the import tariff exposure estimates in perspective relative to foreign retaliatory export tariffs, we calculate the ad valorem tariff equivalent (AVE) of the U.S. import tariffs. We use the estimated coefficient on the import tariff exposure measures $\left(\Gamma_{Q_{t}-0}\right)$, distribution of the exposure measures $\left(I T E_{p}\right)$, and the coefficient on the elasticity of the retaliatory tariff effects $\left(\theta_{\tau}\right)$. The ad valorem equivalent of import tariffs friction on supply chains is

$$
\tau^{A V E}=\exp \left(\frac{\Gamma_{Q_{t}-0} \times I T E_{p}}{\theta_{\tau}}\right)-1
$$

The AVE measures the change in foreign tariffs on U.S. exports that would generate an equivalent change in export growth as relative to levels of the $I T E_{p}$ measure. ${ }^{36}$ At the mean of the $I T E_{p}=0.11$, using the coefficients in column (2) of Table 10, the $A V E$ of the supply chain effect varies from about 0.5 to more than $2 \%$, depending on the quarter. Using the average of quarterly coefficients by year as above, we plot the AVE in Figure 4 from zero to two standard deviations above the mean of ITE. In 2018, the AVE tariff change at the mean

\footnotetext{
${ }^{35}$ Note that the average of all 8 quarterly coefficients is roughly equal to the pooled coefficient in Table 7. Moreover, the average annual effect coefficient is -0.077 for the months of 2019 Q4, but the two-year cumulative coefficient, summing up $2018 \mathrm{Q} 4$ and 2019 Q4, is $-0.097-0.077=-0.174$.

${ }^{36}$ Handley and Limao (2017) undertake a similar exercise to compare effects of trade policy uncertainty with other policies.
} 
is nearly $1 \%$. But in 2019, when the third wave of China tariffs had been in place the entire year, the AVE is about $1.5 \%$ and as high as $4 \%$ for products with exposure more than two standard deviations above the mean. At the higher end, these AVE tariffs are comparable to the average U.S. statutory Most-Favored Nation tariff on all countries without a free trade agreement. More importantly, these are the frictions applied to the growth for the average country-product export variety. These are large drags on export growth, especially when recalling the direct tariff retaliation on U.S. goods affected only $8 \%$ of U.S. exports.

The magnitude of the estimated effects may seem large compared to what appears to be a fairly small cost shock in the aggregate - total customs duties collected in 2018 was $\$ 53.3$ billion or about $2 \%$ of total merchandise imports (U.S. Bureau of Economic Analysis, 2019). However, our import tariff exposure measure is meant to capture not just the effect of actually paying the tariffs, but the comprehensive set of activities that need to be undertaken to reoptimize supply chains in response to the tariffs and accompanying uncertainty. Anecdotally, U.S. firms have described these effects as significant to their operations, perhaps even more important than the actual direct increase in costs from the tariffs themselves. If exporters choose to drop out of importing and exporting altogether in response to new tariffs on intermediate inputs, our measure would still capture the effects of that decision on total export growth. Thus, even though we do not take a position on precisely how the increase in costs transmits through the supply chains of affected firms, our estimated effects encompass a wide range of potential responses by U.S. exporters to the new import tariffs.

\subsection{Decomposition of Effects}

The $I T E_{p}$ measures are nested and allow us to decompose the strengths of the supplychain linkages embedded in the different concepts of imported product relatedness. The baseline exposure measure captures the supply chain effects of import tariffs. In contrast, the broad measure reflects an overall sensitivity of exports to any import tariffs, even in unrelated categories; while the narrow measure reflects only the HS6 products with the closest characteristics to those products receiving import tariffs.

We test the relative importance of each linkage by computing the residual differences of

broader measures relative to a more narrow measure. For example, ITE $E_{p}^{\text {Broad }}-I T E_{p}$ reflects the residual share of product $p$ exporters in the broad measure exposed to any tariff that were not exposed to import tariffs on a product in the same group of HS4 products. The 
nesting implies that the following identities will hold

$$
\begin{aligned}
I T E_{p}^{\text {Broad }} & =\left[I T E_{p}^{\text {Broad }}-I T E_{p}\right]+I T E_{p} \\
I T E_{p}^{\text {Broad }} & =\left[I T E_{p}^{\text {Broad }}-I T E_{p}^{\text {Narrow }}\right]+I T E_{p}^{\text {Narrow }} \\
I T E_{p}^{\text {Broad }} & =\left[I T E_{p}^{\text {Broad }}-I T E_{p}\right]+\left[I T E_{p}-I T E_{p}^{\text {Narrow }}\right]+I T E_{p}^{\text {Narrow }} .
\end{aligned}
$$

We can thus regress the 12-month change in log exports on the right-hand sides of Equations (9a) through (9c) to decompose the importance of each exposure measure. Table 11 illustrates the results from this exercise. As column (1) shows, like the post-2017 interaction, the coefficient on a post-2018Q3 indicator interacted with the import tariff exposure measure is negative and significant. ${ }^{37}$ Column (2) includes the baseline exposure measure, ITE $E_{p}$, with an indicator for the post-2018Q3 period, as well as, for each product, $p$, the difference between $I T E_{p}^{\text {Broad }}$ and $I T E_{p}$ from the RHS of equation (9a). The baseline measure remains negative and significant, increasing in magnitude relative to column (1). The difference measure is statistically significant but smaller in relative magnitude, indicating that variation at the HS4 level of supply chain linkages is a larger driver of the results. Column (4) repeats the exercise, but using the narrow measure combined with the difference between $I T E_{p}^{\text {Broad }}$ and $I T E_{p}^{\text {Narrow }}$ from $(9 \mathrm{~b})$. The difference between the broad and narrow measure is negative and significant alongside the narrow measure. In column (5), we use the full breakdown from equation (9c). The narrow coefficient and the baseline-narrow ITE difference coefficients are both negative and significant and larger in absolute value than the coefficient on the broad-baseline difference coefficient.

The results in Table 11 permit a simple counterfactual exercise. How much higher would export growth have been if the import tariffs were on products less important to firms' supply chains? The mean of the broad measure is 0.55 . Of this, the fraction 0.05 is from exporters with narrow exposure (same HS6) and an additional 0.06 is exporters with only baseline exposure (same HS4). Using column (5) of Table 11, the effect at the mean from the narrow and baseline net of narrow are $(-0.143 \times 0.05)-(0.116 \times 0.06)=-0.014$, or about 1.4 log points on average from 2018Q3-2019Q4. If we assume, counterfactually, that the tariffed products were not part of the exporters supply chains, i.e. shift those products into the residual of the broad measure, then the impact falls to only $-0.9 \log$ points $(-0.083 \times 0.11)$, which reduces the impact by about $35 \%$. So conservatively, the exporters in this counterfactual continue to pay tariffs on imports, but the drag on export

\footnotetext{
${ }^{37}$ For this decomposition, we focus on the post-2018Q3 period, based on results in Table 10 showing significant impacts of tariffs for these later periods.
} 
growth is notably attenuated when the products are less likely to be part of a supply chain. ${ }^{38}$

\subsection{Robustness Checks}

Our main finding is that U.S. exports were adversely affected by the imposition of U.S. import tariffs, using our preferred baseline measure of exposure (where affected exports are those in the same HS4 category as the import tariff being assessed) and also robust to other exposure measures. In this section, we establish the robustness of the baseline result to alternative samples and specifications.

First, we confirm that the particular choice of year, 2016, to construct the import tariff exposure measures is not driving our results. Table 12 recreates all three import tariff exposure measures by averaging firm-level data across 2014-2016 to allay concerns that our results may be driven by choice of a single base year. We find that the results remain negative and statistically significant across all three measures. ${ }^{39}$ Table 13 shows that the quarterly results under this alternative exposure measure are also maintained.

Second, we confirm that our results are not being driven by exports to any particular destination. U.S. exports to China declined substantially in the wake of trade tensions flaring in 2018, a decline that may be causing our results to appear stronger than they would otherwise be. Furthermore, since U.S. import tariffs were mostly assessed on imports from China, there may be a particular relationship between U.S. imports from China and U.S. exports to China that is driving our results. This is ruled out in part by the evidence in Figure 1 showing no particular set of countries or products explains weak export growth. Our inclusion of country-time and country-industry fixed effects already addresses these concerns, but some spurious correlations between our measure of particular country groups or products may remain.

Table 14 shows our results are robust to excluding China or other major geographic regions of the world. Column (1) of Table 14 presents regression results after excluding U.S. exports to China. The $I T E_{p}$ measure interacted with post-2018Q3 indicator yield very similar results to the overall result from column (1) in Table 10 even after excluding exports from China. This suggests that many tariffed imports from China were inputs to output exported to the rest of the world. The remaining columns, (2) through (8), exclude U.S. exports to North America, Central America, South America, Europe, Asia, Australia and Oceania, and Africa, respectively. The results are all in line with the baseline result,

\footnotetext{
${ }^{38}$ We find the same attenuation of $35 \%$ by taking the ratio of the coefficients on $I T E_{p}$ and the broad residual in column (2) of Table 11 , e.g. $1-(0.083 / 0.128)=35 \%$.

${ }^{39}$ See Table 4 for summary statistics.
} 
indicating that there is no single region driving our main negative finding. That said, it is interesting to note that excluding exports to Asia (column 6) results in a coefficient estimate about $30 \%$ less negative than other specifications. This suggests that import tariffs had a more deleterious impact on U.S. exports to Asia relative to other regions. ${ }^{40}$

Third, we explore whether the timing of the various waves of retaliation over the 20182019 period may be driving the overall decline in exports and causing our results to be stronger. The actual amount of the retaliatory tariff may also matter in a non-linear manner such that our current control for retaliatory tariffs may not reflect their full impact on exports. Thus, in column (1) of Table 15, we exclude all export products that faced any retaliation whatsoever over our time period. ${ }^{41}$ Removing these categories does little to alter our overall result.

Fourth, we confirm the robustness of our results to using a consistent set of HS codes over the sample period which encompasses a switch in HS nomenclature in 2017 relative to the HS 2012 nomenclature in place from 2012-2016. Throughout the analysis above, we used only those HS6 export codes that were not merged or split with other codes over time to avoid aggregating potentially unrelated product trade flows or import tariffs together. We also include a robustness check where include all the concorded HS codes. ${ }^{42}$ In column (2) of Table 15, we add about 100,000 observations but results remain very similar to the baseline.

Finally, we consider a cost based import tariff exposure measure that varies by country and time. Thus far we have been agnostic about how exactly the increase in import tariffs is affecting exporters. All that matters for the above specifications is whether an exporter was potentially subject to tariffs but not the tariff rates. Some research has found that the tariff burden is falling directly on U.S. businesses rather than foreign companies, so part of our results likely stem from the direct increase in input costs (Amiti et al., 2019; Cavallo et al., 2019). To check this, we consider a different import tariff exposure measure that generates the implied dollar value increase in duties paid, defined as

$$
I T E_{p c}^{\text {Cost }}=\frac{\text { ImpliedDuties }}{\text { T,All }, 2016}
$$

\footnotetext{
${ }^{40}$ Since excluding China does not generate a similar reduction, the result here is consistent with spillovers throughout "Factory Asia" to supply chains where China plays a central role. Our exposure measure does not distinguish between upstream and downstream production. So this may reflect a reduction in tariffed Chinese inputs feeding through to U.S. exports to the rest of Asia. Alternatively, U.S. exports to Thailand or Korea may fall if a later production stage in China faces new U.S. tariffs as an import.

${ }^{41}$ We continue to not include either the September 1, 2019 U.S. tariff increases or the subsequent retaliation in this analysis.

${ }^{42}$ Specifically, we aggregate values and average tariff into a unique 2012 HS nomenclature code that is consistent over time. See Appendix A for more details.
} 
where ImpliedDuties ${ }_{p c, 2016}^{T, A l l}$ measures the implied value of new duties borne by exporters buying a product $p$ from source country $c$ (tariff rate increase $\times$ value of imports in 2016); ImportValue $_{p c, 2016}$ is the total value of imports in a HS6 product and country pair in 2016. $I T E_{p c}^{\text {Cost }}$ is a direct measure of increases in input costs as implied by increases in U.S. import tariffs and has a mean of 0.03 , which means that the implied increase in costs from U.S. import tariffs is around $3 \%$ of imports for the average product-country pair. The cost measure is interesting in its own right, but it measures only one specific channel through which import tariffs could impact exports: direct increases in input costs that may not fully reflect a variety of other policy induced fixed and switching costs within the supply chain. Nevertheless, the coefficient on the interaction between $I T E_{p c}^{\text {Cost }}$ measure and a post-2018Q3 indicator in column (3) of Table 15, indicates that there is a statistically significant and negative impact on U.S. export growth.

\section{Concluding Remarks}

We provide empirical evidence that increases in U.S. import tariffs over 2018-2019 significantly dampened U.S. export growth. Using detailed firm-level microdata to assess the incidence of tariffs on firms in 2016, before the onset of the tariff war, we find that almost one fourth of U.S. exporters imported products subject to new import tariffs. Moreover, these firms account for more than $80 \%$ of U.S. exports by value. Affected firms were disproportionately larger than the average exporter in term of total exports, employment, and number of establishments. The incidence of these tariffs is non-trivial for U.S. firms in general. Over $30 \%$ of U.S. firms and employment in the non-farm private sector are subject to new import tariffs. The implied duties per worker, based on 2016 import bundles, are $\$ 900$ per worker overall and about $\$ 1,600$ in the manufacturing sector.

We match U.S. exporters of specific products to the basket of products that they also import. Because some of those imported products will eventually face new import tariffs in 2018-2019, we can construct import tariff exposure measures for over 5,000 detailed, export products from the firm-level microdata. Our generalized difference-in-differences estimates imply that export growth was 1 log point lower on average in 2018-2019, and up to $2 \log$ points lower from late 2019, for the average product affected by U.S. import tariffs. By 2019, this spillover friction from import tariffs to exports was equivalent to an ad valorem tariff of about $1.5 \%$ on U.S. exports at mean exposure and 3-4\% for products one or two standard deviations above the mean. Moreover, the export growth reductions would have been 35\% smaller if the new import tariffs were not levied on products likely to be part of the average firm's supply chain. 
More broadly, our novel approach combining detailed firm-level trade transactions data with higher frequency public-use trade data enables estimation of near contemporaneous impacts of trade policy in the presence of global supply chains. We show that, in practice, trade policy designed to avoid tariffs on consumer goods may disproportionately impact imported inputs, spilling over to affect exports of other products to third countries. Moreover, research estimating the direct trade, price and welfare impacts of U.S. import tariffs and subsequent retaliation by trade partners that omits the indirect the supply chain spillovers are likely to understate the total impact on firms and their workers. 


\section{References}

Almunia, Miguel, Pol Antrás, David Lopez-Rodriguez, and Eduardo Morales, "Venting Out: Exports During a Domestic Slump," 2018. mimeo.

Amiti, Mary, Stephen J. Redding, and David Weinstein, "The Impact of the 2018 Trade War on U.S. Prices and Welfare," Journal of Economic Perspectives, 2019, 33 (4), $187-210$.

Baldwin, Richard, The Great Convergence: Information Technology and the New Globalization, Harvard University Press, 2016.

Benguria, Felipe and Felipe Saffie, "Dissecting the Impact of the 2018-2019 Trade War on U.S. Exports," 2019. mimeo.

Bernard, Andrew B., J. Bradford Jensen, Stephen J. Redding, and Peter K. Schott, "Global Firms," Journal of Economic Literature, 2018, 56 (2), 565-619.

_, Teresa C. Fort, Valerie Smeets, and Frederic Warzynski, "Heterogeneous Globalization: Offshoring and Reorganization," 2020. NBER Working Paper 26854.

Blanchard, Emily J., Chad P. Bown, and Davin Chor, "Did Trump's Trade War Impact the 2018 Election?," 2019. NBER Working Paper 26434.

_, , , and Robert C. Johnson, "Global Supply Chains and Trade Policy," 2016. NBER Working Paper 21883.

Boehm, Christoph E., Aaron Flaaen, and Nitya Pandalai-Nayar, "Input Linkages and the Transmission of Shocks: Firm-level Evidence from the 2011 Tohoku Earthquake," Review of Economics and Statistics, 2019, 101 (1), 60-75.

Bown, Chad P., "U.S.-China Trade War: The Guns of August," 2019. Trade Investment Policy Watch, Peterson Institute of International Economics.

- and Eva Zhang, "Measuring Trump's 2018 Trade Protection: Five Takeaways," 2019. Trade Investment Policy Watch, Peterson Institute of International Economics.

_ and Melina Kolb, "Trump's Trade War Timeline: An Up-to-Date Guide," 2019. Trade Investment Policy Watch, Peterson Institute of International Economics.

_ , Paola Conconi, Aksel Erbahar, and Lorenzo Trimarchi, "Trade Protection Along Supply Chains," 2020. mimeo.

Bunge, Jacob, Kirk Maltais, and Lucy Craymer, "China Deals 'Body Blow' to Struggling U.S. Farm Belt," The Wall Street Journal, 2019, August 6, 2019.

Caldara, Dario, Matteo Iacoviello, Patrick Molligo, Andrea Prestipino, and Andrea Raffo, "The Economic Effects of Trade Policy Uncertainty," 2019. mimeo. 
Cavallo, Alberto, Gita Gopinath, Brent Neiman, and Jenny Tang, "Tariff Passthrough at the Border and at the Store: Evidence from US Trade Policy," 2019. NBER Working Paper 26396.

Fajgelbaum, Pablo D., Pinelopi K. Goldberg, Patrick J. Kennedy, and Amit K. Khandelwal, "The Return to Protectionism," The Quarterly Journal of Economics, 2020, 135 (1), 1-55.

Federal Register, "Notice of Determination and Request for Public Comment Concerning Proposed Determination of Action Pursuant to Section 301: China's Acts, Policies, and Practices Related to Technology Transfer, Intellectual Property, and Innovation," https: //www.govinfo.gov/content/pkg/FR-2018-04-06/pdf/2018-07119.pdf April 6, 2018. accessed December 19, 2019.

Federal Reserve Beige Book, "Summary of Commentary on Current Economic Conditions by Federal Reserve District," https://www.federalreserve.gov/monetarypolic y/files/BeigeBook_20191127.pdf November 27, 2019.

Flaaen, Aaron B., Ali Hortaçsu, and Felix Tintlenot, "The Production Relocation and Price Effects of U.S. Trade Policy: The Case of Washing Machines," American Economic Review, 2020, 110 (7), 2103-2127.

- and Justin R. Pierce, "Disentangling the Effects of the 2018-2019 Tariffs on a Globally Connected U.S. Manufacturing Sector," Finance and Economics Discussion Series 2019086, Board of Governors of the Federal Reserve 2019.

Handley, Kyle and Nuno Limao, "Policy Uncertainty, Trade, and Welfare: Theory and Evidence for China and the United States," American Economic Review, 2017, 107 (9), $2731-2783$.

Hummels, David, Jakob Munch, and Chong Xiang, "Offshoring and Labor Markets," Journal of Economic Literature, 2018, 56 (3), 981-1028.

_, Jun Ishii, and Kei-Mu Yi, "The Nature and Growth of Vertical Specialization in World Trade," Journal of International Economics, 2001, 1 (54), 75-96.

_, Rasmus Jørgensen, Jakob Munch, and Chong Xiang, "The Wage Effects of Offshoring: Evidence from Danish Matched Worker-Firm Data," American Economic Review, 2014, 104 (6), 1597-1629.

Irwin, Douglas A., "The Smoot-Hawley Tariff: A Quantitative Assessment," Review of Economics and Statistics, 1998, 80 (2), 326-334.

Jarmin, Ronald S. and Javier Miranda, "The Longitudinal Business Database," 2002. U.S. Census Bureau Center for Economic Studies Working Paper 02-17.

Johnson, Robert and Guillermo Noguera, "A Portrait of Trade in Value-Added Over Four Decades," Review of Economics and Statistics, 2017, 99 (5), 896-911. 
Lovely, Mary E. and Yang Liang, "Trump Tariffs Primarily Hit Multinational Supply Chains, Harm US Technology Competitiveness," Policy Brief, 2018, 18-12, Peterson Institute of International Economics.

Monarch, Ryan, "It's Not You, It's Me: Breakups in U.S.-China Trade Relationships," International Finance Discussion Papers 1165, Board of Governors of the Federal Reserve 2016.

U.S. Bureau of Economic Analysis, "Taxes on Production and Imports," National Income and Product Accounts 2019. Table 3.5.

U.S. Senate Committee on Finance, "Hearing Before the Committee on Finance United States Senate 115th Congress Second Session," https://www.finance. senate.gov/imo /media/doc/36528.pdf, 2018. accessed December 19, 2019.

Waugh, Michael E., "The Consumption Response to Trade Shocks: Evidence from the U.S.-China Trade War," 2019. NBER Working Paper 26353.

World Customs Organization, "HS Nomenclature 2002 Edition," http://www.wcoomd .org/en/topics/nomenclature/instrument-and-tools/hs_nomenclature_previou s_editions/hs_nomenclature_table_2002.aspx 2019. accessed December 19, 2019.

Yi, Kei-Mu, "Can Vertical Specialization Explain the Growth of World Trade," Journal of Political Economy, 2003, 111 (1), 52-102. 
Figure 1. Average Quarterly Country-Product Export Growth 2017Q1-2019Q4 (year-on-year): Total Growth and Progressively Excluding Groups

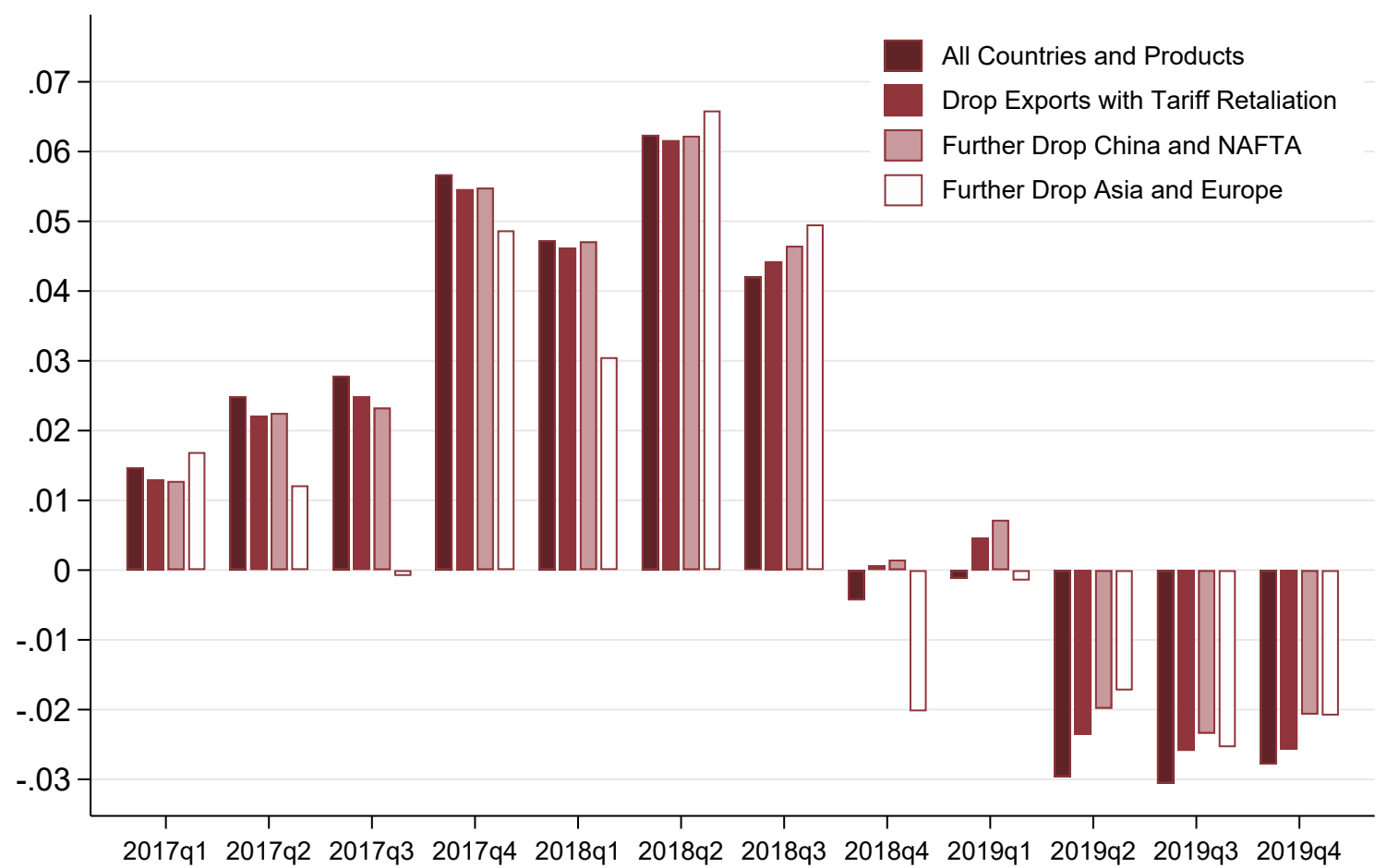

Notes: Bars are average monthly (ln) export growth (year-on-year) within each quarter from 2017Q1-2019Q4. Observations are at the country-product (HS6) level. 
Figure 2. Cumulative Count of New U.S. Import Tariffs on Traded Goods: Country by Tariff Line Basis

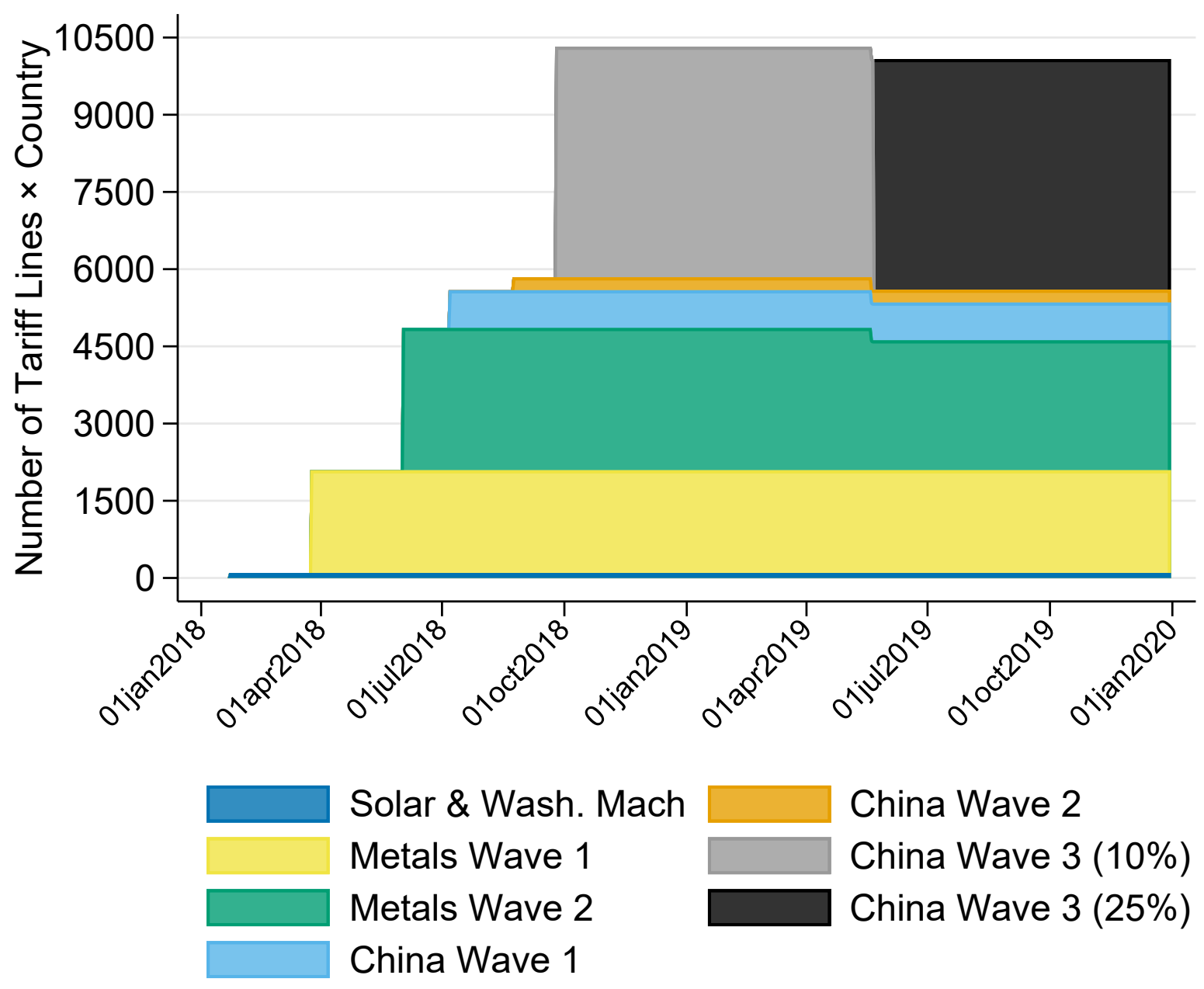

Notes: New U.S. import tariffs from January 2018 to December 2019 matched to 2016 import data with positive annual exports. Observations are at the country-tariff line (HS8) level. Metals Wave 2 reduction reflects country exemption granted in 2019. Product list for China Wave 3 at $10 \%$ and $25 \%$ is unchanged. 
Figure 3. Cumulative Export Growth for Exposed and Non-Exposed HS2 Sectors

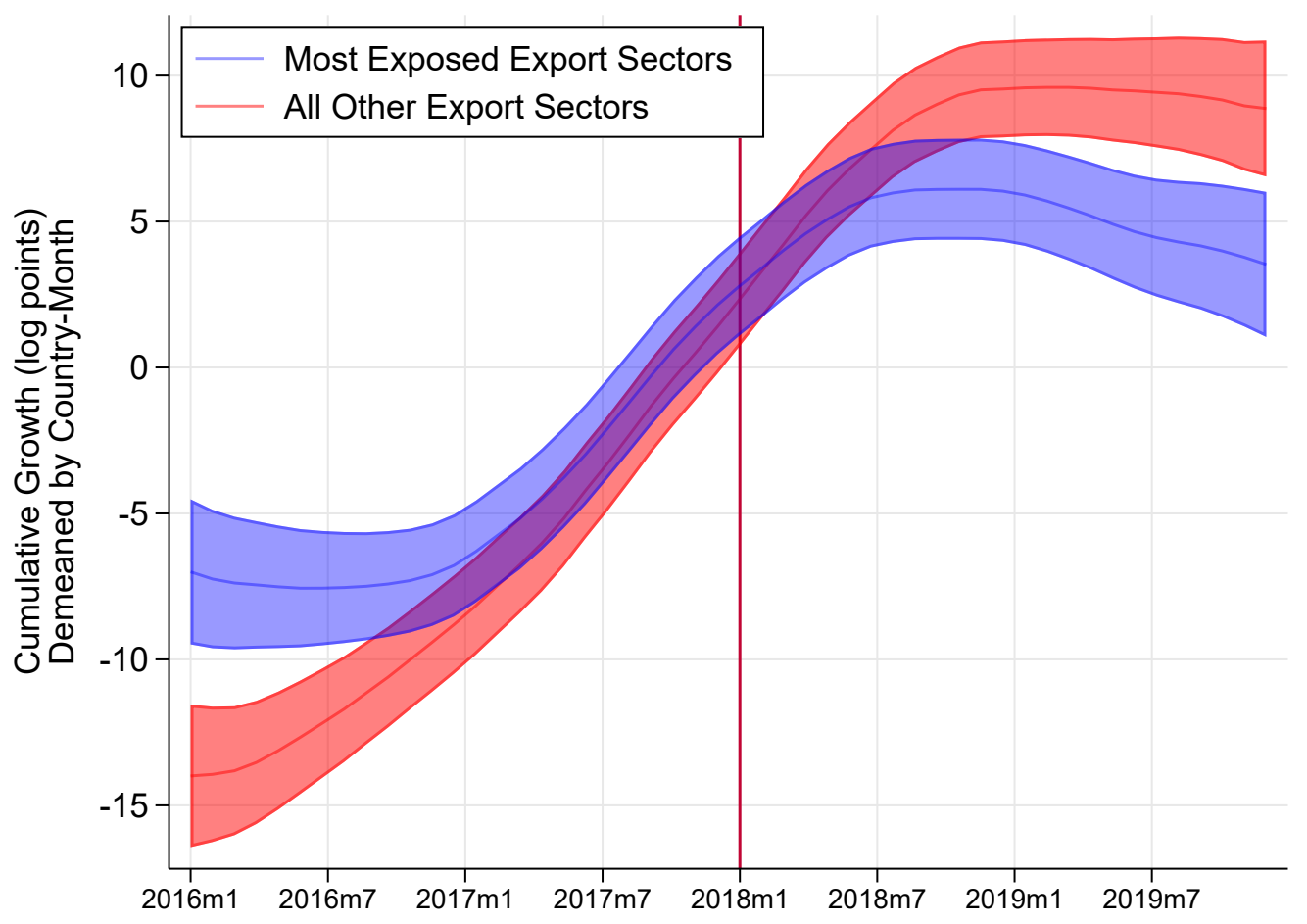

Notes: Local linear polynomial regressions of cumulative aggregate export growth by country and exposure group fit to a monthly time variable. Exports within country are grouped into the five most exposed HS2 sectors according to our $I T E_{p}$ measure (blue) and all other HS2 sectors (red). Each series was centered relative to its country by calendar month by exposure group mean in a balanced panel (i.e. 4 yearly observations per country, exposure group, calendar month). The latter sweeps out country-exposure growth trends and monthly seasonality. Shaded areas are $95 \%$ confidence intervals. The list of exposed sectors can be found in Table 5 . 


\section{Figure 4. Ad Valorem Equivalent Tariff Change on U.S. Export Growth of Import Tariff Exposure}

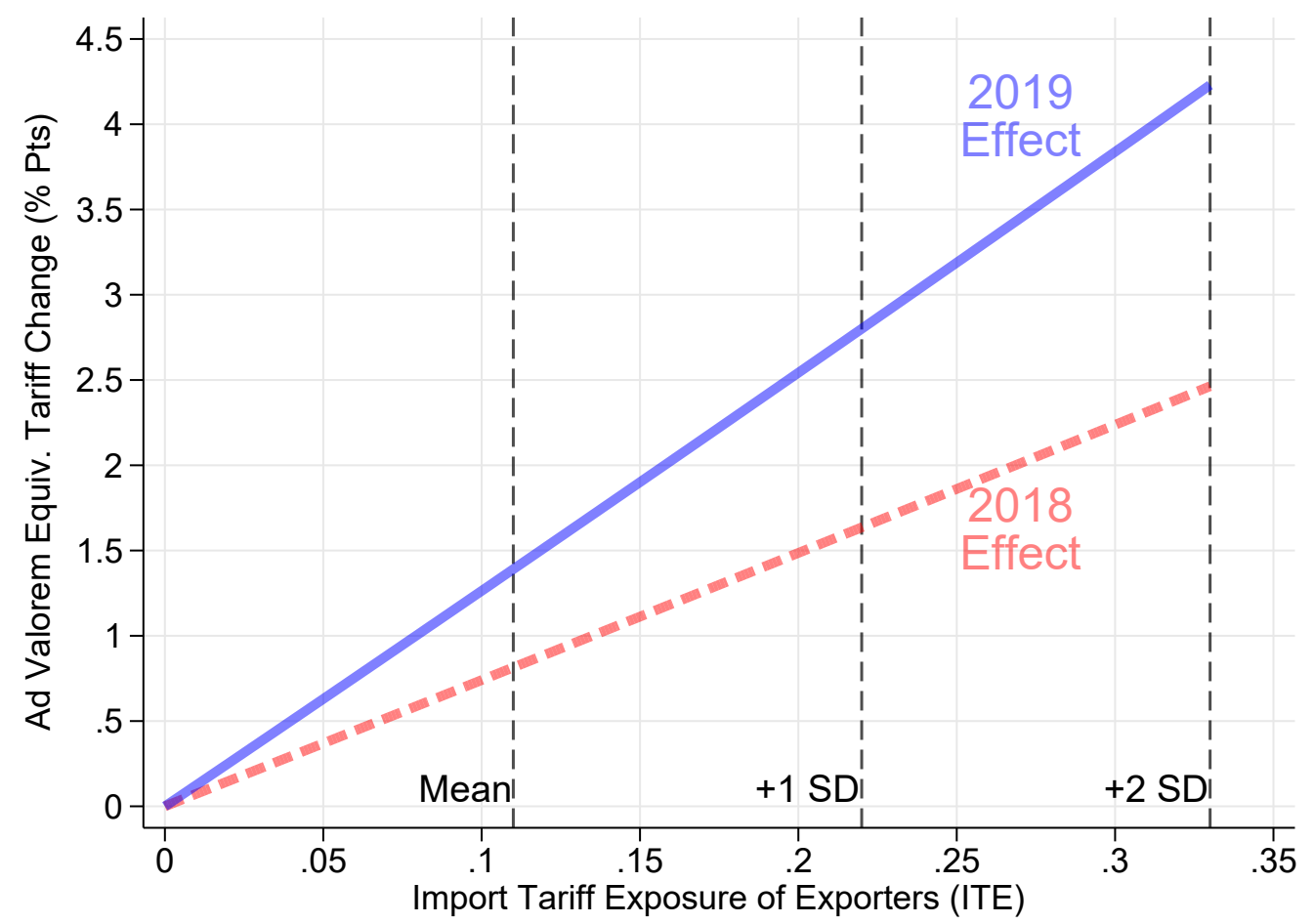

Notes: We compute the ad valorem equivalent tariff (AVE) using the coefficients in Table 10 and equation (8). We average coefficients across quarters from 2018 and 2019. 
Table 1. 2018 Tariff Incidence by 2016 Trade Patterns

\begin{tabular}{lcc}
\hline & Imports & Exports \\
\hline Share of Value & 11.5 & 7.9 \\
Share of Firms & 32.9 & 18.7 \\
Share of Employees & 31.8 & 23.2 \\
Tariffed Share at Affected Firms & 46.5 & 32.5 \\
\hline
\end{tabular}

Notes: "Imports" ("Exports") show statistics for all importers (exporters) impacted by U.S.-imposed import (foreign retaliatory export) tariffs. "Value" is the share of trade impacted by tariffs; "Firms" is the share of firms affected by tariffs; "Share of Employees" is the share of private, non-farm employees working at affected firms, and "Tariffed Share at Affected Firms" is average trade value at affected firms that face tariffs.

Source: Authors' calculations using 2016 LFTTD.

Table 2. Average characteristics of firms affected by new tariffs in 2018-2019

Panel A: Importers

\begin{tabular}{lccc}
\hline & Tariffed Importers & All Importers & All Firms \\
\hline Employment & 430.9 & 212 & 24.0 \\
Establishments & 9.3 & 4.8 & 1.3 \\
Age & 17.6 & 18.0 & 14.1 \\
Pay/Worker $(\$ 1000 \mathrm{~s})$ & 57.8 & 57.5 & 29.5 \\
\hline Panel B: Exporters & & & \\
\hline & Tariffed Exporters & All Exporters & All Firms \\
\hline Employment & 720.3 & 241.7 & 24.0 \\
Establishments & 14.8 & 5.8 & 1.3 \\
Age & 22.5 & 18.8 & 14.1 \\
Pay/Worker $(\$ 1000 \mathrm{~s})$ & 64.2 & 57.1 & 29.6 \\
\hline
\end{tabular}

Notes: Average firm characteristics by firm sample in top row of Panel A and B. Annual pay per worker in thousands of dollars. All firm details are based on 2016 firm-level data, the latest year available.

Source: Authors' calculations using 2016 LFTTD and LBD. 
Table 3. Tariff Incidence by Affected Sectors

\begin{tabular}{lccc}
\hline & $\begin{array}{c}\text { Importers } \\
\text { Employment Share }\end{array}$ & $\begin{array}{c}\text { Exporters } \\
\text { Employment Share }\end{array}$ & $\begin{array}{c}\text { Implied Duties } \\
\text { per Worker }\end{array}$ \\
\hline Manufacturing & 0.65 & 0.63 & $\$ 1,595$ \\
Wholesale & 0.51 & 0.38 & $\$ 5,049$ \\
Retail & 0.60 & 0.44 & $\$ 364$ \\
Other & 0.21 & 0.13 & $\$ 314$ \\
\hline Total & 0.32 & 0.23 & $\$ 893$ \\
\hline
\end{tabular}

Notes: Manufacturing is defined as all sectors within NAICS 31-33; Wholesale is defined as all sectors within NAICS 42; Retail is defined as all sectors within NAICS 44 and 45; and Other includes all other sectors except 92. Duty-per-worker weighted by sectoral employment. All calculations are based on 2016 firm-level data, the latest year available. See text for futher details.

Source: Authors' calculations using 2016 LFTTD and LBD.

Table 4. Summary Statistics on Import Tariff Exposure

\begin{tabular}{lccc}
\hline & $I T E_{p}^{\text {Broad }}$ & $I T E_{p}$ & $I T E_{p}^{\text {Narrow }}$ \\
\hline 2016 & 0.545 & 0.111 & 0.050 \\
& $(0.127)$ & $(0.109)$ & $(0.063)$ \\
2014-2016 Average & 0.526 & 0.105 & 0.047 \\
& $(0.125)$ & $(0.103)$ & $(0.060)$ \\
Tranche 1: Solar/Washing & 0.060 & 0.001 & 0.0002 \\
& $(0.042)$ & $(0.012)$ & $(0.005)$ \\
Tranche 2: Metals & 0.209 & 0.006 & 0.003 \\
& $(0.113)$ & $(0.041)$ & $(0.022)$ \\
Tranche 3: China & 0.527 & 0.104 & 0.047 \\
& $(0.125)$ & $(0.107)$ & $(0.062)$ \\
\hline
\end{tabular}

Notes: This table displays means and standard deviations in parentheses of the three ITE measures described in Section 3 for our regression sample. The first row displays statistics for ITE measures constructed using 2016 data. The second row displays statistics for ITE measures constructed using data averaged over 2014-2016. Rows three through five, display statistics for ITE measures by the three main tranches of tariffs using 2016 data. Tranche 1 refers solar products and washing machines tariffs; Tranche 2 refers to aluminum and steel tariffs; and Tranche 3 refers to tariffs on goods originating in China.

Source: Authors' calculations using 2014-2016 LFTTD. 
Table 5. Export Sectors that are the Most and Least Exposed to Import Tariffs

Panel A: Most Exposed

\begin{tabular}{ll}
\hline HS2 & Product Description \\
\hline 29 & Organic chemicals \\
85 & Electrical machinery and equipment and parts thereof \\
72 & Iron and steel \\
84 & Nuclear reactors, boilers, machinery and mechanical appliances \\
73 & Articles of iron or steel \\
\hline
\end{tabular}

Panel B: Least Exposed

\begin{tabular}{ll}
\hline HS2 & Product Description \\
\hline 67 & Prepared feathers/down; artificial flowers; articles of human hair \\
14 & Vegetable plaiting materials \\
27 & Mineral fuels, mineral oils and products of their distillation \\
47 & Pulp of wood or of other fibrous cellulosic material \\
23 & Residues from food industry, animal fodder, offal \\
\hline
\end{tabular}

Notes: This table reports the five most and five least exposed HS2 product categories with respect to the 2018-2019 import tariffs. HS2 sectors are ranked by the total number of HS6 products with an $I T E_{p}$ measure greater than the 75 th percentile of the overall $I T E_{p}$ distribution. Disclosure avoidance protocols preclude releasing a full ranking.

Source: Authors' calculations from 2016 LFTTD.

Table 6. Export Growth and Import Tariff Exposure

\begin{tabular}{lccc}
\hline & $(1)$ & $(2)$ & $(3)$ \\
\hline$\Delta \ln \left(1+\tau_{p c t}\right)$ & $-0.910^{* * *}$ & $-0.895^{* * *}$ & $-0.922^{* * *}$ \\
& $(0.124)$ & $(0.143)$ & $(0.121)$ \\
$I T E_{p} \times I(>2017 Q 4)$ & $-0.046^{* *}$ & $-0.045^{* *}$ & $-0.092^{* * *}$ \\
& $(0.022)$ & $(0.022)$ & $(0.025)$ \\
\hline Fixed Effects & $c t, p q$ & $c t, p q, c I$ & $c t, p q, c I, I t$ \\
Observations & $4,208,229$ & $4,208,226$ & $4,208,226$ \\
\hline
\end{tabular}

Notes: ${ }^{*} \mathrm{p}<10 \%$; ** $\mathrm{p}<5 \%$; *** $\mathrm{p}<1 \%$. Robust standard errors in parentheses, clustered by HS6 product. The ITE measure is generated using data from the 2016 LFTTD. Fixed effects denoted by country $(c)$, month $(t)$, and HS section $(I)$ and their interactions. All specifications include HS6calendar quarter $(p q)$ fixed effects. 
Table 7. Export Growth and Import Tariff Exposure - Narrow, Baseline, and Broad Measures

\begin{tabular}{lccc}
\hline & $(1)$ & $(2)$ & $(3)$ \\
\hline$\Delta \ln \left(1+\tau_{p c t}\right)$ & $-0.922^{* * *}$ & $-0.929^{* * *}$ & $-0.923^{* * *}$ \\
& $(0.121)$ & $(0.121)$ & $(0.121)$ \\
$I T E_{p} \times I(>2017 Q 4)$ & $-0.092^{* * *}$ & & \\
& $(0.017)$ & & \\
$I T E_{p}^{\text {Broad }} \times I(>2017 Q 4)$ & & $-0.097^{* * *}$ & \\
& & $(0.025)$ & \\
$I T E_{p}^{\text {Narrow }} \times I(>2017 Q 4)$ & & & $-0.123^{* * *}$ \\
& & & $(0.039)$ \\
\hline Fixed Effects & $c t, p q, c I$, It & $c t, p q, c I$, It & $c t, p q, c I, I t$ \\
Observations & $4,208,226$ & $4,208,226$ & $4,208,226$ \\
\hline
\end{tabular}

Notes: ${ }^{*} \mathrm{p}<10 \%$; ${ }^{* *} \mathrm{p}<5 \%$; ${ }^{* * *} \mathrm{p}<1 \%$. Robust standard errors in parentheses, clustered by HS6 product. The ITE measures are generated using data from the 2016 LFTTD. Fixed effects denoted by country $(c)$, month $(t)$, and HS section $(I)$ and their interactions. All specifications include HS6calendar quarter $(p q)$ fixed effects.

Table 8. Export Growth and Import Tariff Exposure Pre-Tariff Period

\begin{tabular}{|c|c|c|c|}
\hline & (1) & $(2)$ & (3) \\
\hline$\Delta \ln \left(1+\tau_{p c t}\right)$ & - & - & - \\
\hline$I T E_{p} \times I(>2016 Q 4)$ & $\begin{array}{c}0.046 \\
(0.035)\end{array}$ & & \\
\hline$I T E_{p}^{\text {Broad }} \times I(>2016 Q 4)$ & & $\begin{array}{c}0.039 \\
(0.057)\end{array}$ & \\
\hline$I T E_{p}^{\text {Narrow }} \times I(>2016 Q 4)$ & & & $\begin{array}{c}0.009 \\
(0.037)\end{array}$ \\
\hline Fixed Effects & $c t, p q, c I, I t$ & $c t, p q, c I, I t$ & $c t, p q, c I, I t$ \\
\hline Observations & $2,111,899$ & $2,111,899$ & 2,111,899 \\
\hline
\end{tabular}

Notes: ${ }^{*} \mathrm{p}<10 \%$; ${ }^{* *} \mathrm{p}<5 \%$; ${ }^{* *} \mathrm{p}<1 \%$. Robust standard errors in parentheses, clustered by HS6 product. The ITE measures are generated using data from the 2016 LFTTD. Fixed effects denoted by country $(c)$, month $(t)$, and HS section $(I)$ and their interactions. All specifications include HS6calendar quarter $(p q)$ fixed effects. 
Table 9. Export Growth and Import Tariff Exposure by Tariff Tranche

\begin{tabular}{lccc}
\hline & $I T E_{p}$ & $I T E_{p}^{\text {Broad }}$ & ITE $E_{p}^{\text {Narrow }}$ \\
\hline$\Delta \ln \left(1+\tau_{p c t}\right)$ & $-0.913^{* * *}$ & $-0.938^{* * *}$ & $-0.915^{* * *}$ \\
& $(0.120)$ & $(0.120)$ & $(0.121)$ \\
Interacted Variable & & & \\
$T 1 \times I(>2017 Q 4)$ & $-0.702^{* * *}$ & $-0.222^{* * *}$ & $-0.903^{* * *}$ \\
& $(0.150)$ & $(0.084)$ & $(0.115)$ \\
$T 2 \times I(>2017 Q 4)$ & $-0.188^{* *}$ & $0.085^{* *}$ & $-0.268^{* *}$ \\
& $(0.081)$ & $(0.038)$ & $(0.128)$ \\
$T 3 \times I(>2017 Q 4)$ & $-0.070^{* *}$ & $-0.083^{* * *}$ & $-0.105^{* * *}$ \\
& $(0.025)$ & $(0.029)$ & $(0.040)$ \\
\hline Fixed Effects & $c t, p q, c I$, It & $c t, p q, c I, I t$ & $c t, p q, c I, I t$ \\
Observations & $4,208,226$ & $4,208,226$ & $4,208,226$ \\
\hline
\end{tabular}

Notes: ${ }^{*} \mathrm{p}<10 \%$; ** $\mathrm{p}<5 \%$; *** $\mathrm{p}<1 \%$. Robust standard errors in parentheses, clustered by HS6 product. The ITE measures are generated using data from the 2016 LFTTD. T1 refers to the respective $I T E_{p}$ measure using only the import tariffs on washing machines and solar products; T2 refers to the $I T E_{p}$ measure using only the import tariffs on steel and aluminum; and T3 to the $I T E_{p}$ measure using only the import tariffs on goods from China. Fixed effects denoted by country $(c)$, month $(t)$, and HS section $(I)$ and their interactions. All specifications include HS6-calendar quarter $(p q)$ fixed effects. 
Table 10. Export Growth and Import Tariff Exposure, Quarterly Effects

\begin{tabular}{|c|c|c|c|}
\hline & (1) & $(2)$ & $(3)$ \\
\hline & $I T E_{p}$ & $I T E_{p}^{\text {Narrow }}$ & $I T E_{p}^{\text {Broad }}$ \\
\hline$\Delta \ln \left(1+\tau_{p c t}\right)$ & $\begin{array}{c}-0.922^{* * *} \\
(0.121)\end{array}$ & $\begin{array}{c}-0.920^{* * *} \\
(0.121)\end{array}$ & $\begin{array}{c}-0.930^{* * *} \\
(0.121)\end{array}$ \\
\hline \multicolumn{4}{|c|}{$\begin{array}{l}\text { ITE (column variable) } \\
\times \text { Quarterly Indicator }\end{array}$} \\
\hline$\times 2018 Q 1$ & $\begin{array}{l}-0.049 \\
(0.045)\end{array}$ & $\begin{array}{l}-0.064^{*} \\
(0.069)\end{array}$ & $\begin{array}{l}-0.81^{*} \\
(0.046)\end{array}$ \\
\hline$\times 2018 Q 2$ & $\begin{array}{l}-0.049 \\
(0.045)\end{array}$ & $\begin{array}{l}-0.045 \\
(0.069)\end{array}$ & $\begin{array}{c}-0.107^{* *} \\
(0.045)\end{array}$ \\
\hline$\times 2018 Q 3$ & $\begin{array}{l}-0.077^{*} \\
(0.045)\end{array}$ & $\begin{array}{c}-0.143^{* *} \\
(0.071)\end{array}$ & $\begin{array}{l}-0.081^{*} \\
(0.047)\end{array}$ \\
\hline$\times 2018 Q 4$ & $\begin{array}{c}-0.097^{* *} \\
(0.047)\end{array}$ & $\begin{array}{c}-0.162^{* *} \\
(0.072)\end{array}$ & $\begin{array}{l}-0.074 \\
(0.047)\end{array}$ \\
\hline$\times 2019 Q 1$ & $\begin{array}{c}-0.074^{*} \\
(0.043)\end{array}$ & $\begin{array}{l}-0.107 \\
(0.069)\end{array}$ & $\begin{array}{c}-0.118^{* * *} \\
(0.040)\end{array}$ \\
\hline$\times 2019 Q 2$ & $\begin{array}{c}-0.127^{* * *} \\
(0.042)\end{array}$ & $\begin{array}{c}-0.149^{* *} \\
(0.067)\end{array}$ & $\begin{array}{c}-0.150^{* * *} \\
(0.042)\end{array}$ \\
\hline$\times 2019 Q 3$ & $\begin{array}{c}-0.185^{* * *} \\
(0.043)\end{array}$ & $\begin{array}{c}-0.254^{* * *} \\
(0.066)\end{array}$ & $\begin{array}{c}-0.153^{* * *} \\
(0.043)\end{array}$ \\
\hline$\times 2019 Q 4$ & $\begin{array}{c}-0.077^{*} \\
(0.044)\end{array}$ & $\begin{array}{l}-0.061 \\
(0.069)\end{array}$ & $\begin{array}{l}-0.016 \\
(0.045)\end{array}$ \\
\hline $\begin{array}{l}\text { Fixed Effects } \\
\text { Observations }\end{array}$ & $\begin{array}{c}c t, p q, c I, I t \\
4,208,226\end{array}$ & $\begin{array}{c}c t, p q, c I, I t \\
4,208,226\end{array}$ & $\begin{array}{c}c t, p q, c I, I t \\
4,208,226\end{array}$ \\
\hline
\end{tabular}

Notes: ${ }^{*} \mathrm{p}<10 \%$; ${ }^{* *} \mathrm{p}<5 \%$; ${ }^{* *} \mathrm{p}<1 \%$. The regressions in this table are generated according to Equation (7). Robust standard errors in parentheses, clustered by HS6 product. The ITE measures are generated using data from the 2016 LFTTD. Fixed effects denoted by country $(c)$, month $(t)$, and HS section $(I)$ and their interactions. All specifications include HS6-calendar quarter $(p q)$ fixed effects. 


\section{Table 11. Export Growth and Import Tariff Exposure: Decomposition of Supply Chain Margins}

\begin{tabular}{|c|c|c|c|c|c|}
\hline & $\begin{array}{c}(1) \\
\text { Baseline }\end{array}$ & $\begin{array}{c}(2) \\
\text { Broad Net } \\
\text { Baseline }\end{array}$ & $\begin{array}{c}(3) \\
\text { Narrow }\end{array}$ & $\begin{array}{c}(4) \\
\text { Broad Net } \\
\text { Narrow }\end{array}$ & $\begin{array}{c}(5) \\
\text { Fully } \\
\text { Decomposed }\end{array}$ \\
\hline$\Delta \ln \left(1+\tau_{p c t}\right)$ & $\begin{array}{c}-0.916^{* * *} \\
(0.120)\end{array}$ & $\begin{array}{c}-0.927^{* * *} \\
(0.121)\end{array}$ & $\begin{array}{c}-0.923^{* * *} \\
(0.121)\end{array}$ & $\begin{array}{c}-0.927^{* * *} \\
(0.121)\end{array}$ & $\begin{array}{c}-0.926^{* * *} \\
(0.121)\end{array}$ \\
\hline$I T E_{p} \times I(>2018 Q 3)$ & $\begin{array}{c}-0.089^{* * *} \\
(0.026)\end{array}$ & $\begin{array}{c}-0.128^{* * *} \\
(0.031)\end{array}$ & & & \\
\hline \multicolumn{2}{|c|}{$I T E_{p}^{\text {Narrow }} \times I(>2018 Q 3)$} & & $\begin{array}{c}-0.118^{* * *} \\
(0.040)\end{array}$ & $\begin{array}{c}-0.152^{* * *} \\
(0.042)\end{array}$ & $\begin{array}{c}-0.143^{* * *} \\
(0.043)\end{array}$ \\
\hline \multicolumn{6}{|c|}{ Broad Exposure Net of Baseline } \\
\hline \multicolumn{2}{|c|}{$\left[I T E_{p}^{\text {Broad }}-I T E_{p}\right] \times I(>2018 Q 3)$} & $\begin{array}{c}-0.083^{* * *} \\
(0.029)\end{array}$ & & & $\begin{array}{c}-0.083^{* * *} \\
(0.029)\end{array}$ \\
\hline \multicolumn{6}{|c|}{ Broad Exposure Net of Narrow } \\
\hline \multicolumn{2}{|c|}{$\left[I T E_{p}^{\text {Broad }}-I T E_{p}^{\text {Narrow }}\right] \times I(>2018 Q 3)$} & & & $\begin{array}{c}-0.091^{* * *} \\
(0.027)\end{array}$ & \\
\hline \multicolumn{6}{|c|}{ Baseline Exposure Net of Narrow } \\
\hline \multicolumn{2}{|c|}{$\left[I T E_{p}-I T E_{p}^{\text {Narrow }}\right] \times I(>2018 Q 3)$} & & & & $\begin{array}{c}-0.116^{* * *} \\
(0.040)\end{array}$ \\
\hline $\begin{array}{l}\text { Fixed Effects } \\
\text { Observations }\end{array}$ & $\begin{array}{l}c t, p q, c I, I t \\
4.208 .226\end{array}$ & $\begin{array}{l}c t, p q, c I, I t \\
4.208 .226\end{array}$ & $\begin{array}{l}c t, p q, c I, I t \\
4.208 .226\end{array}$ & $\begin{array}{l}c t, p q, c I, I t \\
4.208 .226\end{array}$ & $\begin{array}{l}c t, p q, c I, I t \\
4.208 .226\end{array}$ \\
\hline
\end{tabular}

Notes: ${ }^{*} \mathrm{p}<10 \%$; ${ }^{* *} \mathrm{p}<5 \%$; ${ }^{* * *} \mathrm{p}<1 \%$. Robust standard errors in parentheses, clustered by HS6 product. The ITE measures are generated using data from the 2016 LFTTD. The decomposition regressions in columns (2), (4), and (5) are generated according to (9a) through (9c). Fixed effects denoted by country $(c)$, month $(t)$, and HS section $(I)$ and their interactions. All specifications include HS6-calendar quarter $(p q)$ fixed effects. 
Table 12. Export Growth and Import Tariff Exposure, Compare $\overline{I T E}$ Measures

\begin{tabular}{lccc}
\hline & $(1)$ & $(2)$ & $(3)$ \\
\hline$\Delta \ln \left(1+\tau_{p c t}\right)$ & $-0.922^{* * *}$ & $-0.929^{* * *}$ & $-0.923^{* * *}$ \\
& $(0.121)$ & $(0.121)$ & $(0.121)$ \\
$\overline{I T E}_{p} \times I(>2017 Q 4)$ & $-0.102^{* * *}$ & & \\
& $(0.026)$ & & \\
$\overline{I T E}_{p}^{\text {Broad }} \times I(>2017 Q 4)$ & & $-0.109^{* * *}$ & \\
& & $(0.026)$ & \\
$\overline{I T E}_{p}^{\text {Narrow }} \times I(>2017 Q 4)$ & & & $-0.136^{* * *}$ \\
& & & $(0.041)$ \\
\hline Fixed Effects & $c t, p q, c I$, It & $c t, p q, c I$, It & $c t, p q, c I, I t$ \\
Observations & $4,208,226$ & $4,208,226$ & $4,208,226$ \\
\hline
\end{tabular}

Notes: ${ }^{*} \mathrm{p}<10 \%$; ${ }^{* *} \mathrm{p}<5 \%$; ${ }^{* * *} \mathrm{p}<1 \%$. Robust standard errors in parentheses, clustered by HS6 product. Average ITE measures are generated using LFTTD data from 2014 through 2016. Fixed effects denoted by country $(c)$, month $(t)$, and HS section $(I)$ and their interactions. All specifications include HS6-calendar quarter $(p q)$ fixed effects. 
Table 13. Export Growth and Import Tariff Exposure, Quarterly Effects, Average ITE

\begin{tabular}{|c|c|c|c|}
\hline & (1) & $(2)$ & $(3)$ \\
\hline & $\overline{I T E}_{p}$ & $\overline{I T E}_{p}^{\text {Broad }}$ & $\overline{I T E}_{p}^{\text {Narrow }}$ \\
\hline$\Delta \ln \left(1+\tau_{p c t}\right)$ & $\begin{array}{c}-0.922^{* * *} \\
(0.121)\end{array}$ & $\begin{array}{c}-0.930^{* * *} \\
(0.121)\end{array}$ & $\begin{array}{c}-0.920^{* * * *} \\
(0.121)\end{array}$ \\
\hline \multicolumn{4}{|c|}{$\begin{array}{c}\overline{I T E}(\text { column variable }) \\
\times \text { Quarterly Indicator }\end{array}$} \\
\hline$\times 2018 Q 1$ & $\begin{array}{l}-0.049 \\
(0.047)\end{array}$ & $\begin{array}{l}-0.88^{*} \\
(0.046)\end{array}$ & $\begin{array}{l}-0.077 \\
(0.073)\end{array}$ \\
\hline$\times 2018 Q 2$ & $\begin{array}{l}-0.060 \\
(0.047)\end{array}$ & $\begin{array}{c}-0.131^{* * *} \\
(0.046)\end{array}$ & $\begin{array}{l}-0.061 \\
(0.071)\end{array}$ \\
\hline$\times 2018 Q 3$ & $\begin{array}{c}-0.081^{*} \\
(0.047)\end{array}$ & $\begin{array}{c}-0.143^{* *} \\
(0.048)\end{array}$ & $\begin{array}{c}-0.170^{* *} \\
(0.074)\end{array}$ \\
\hline$\times 2018 Q 4$ & $\begin{array}{c}-0.123^{* *} \\
(0.049)\end{array}$ & $\begin{array}{c}-0.200^{* * *} \\
(0.048)\end{array}$ & $\begin{array}{c}-0.162^{* *} \\
(0.075)\end{array}$ \\
\hline$\times 2019 Q 1$ & $\begin{array}{r}-0.078^{*} \\
(0.045)\end{array}$ & $\begin{array}{c}-0.112^{* * *} \\
(0.041)\end{array}$ & $\begin{array}{l}-0.126^{*} \\
(0.073)\end{array}$ \\
\hline$\times 2019 Q 2$ & $\begin{array}{c}-0.140^{* * *} \\
(0.044)\end{array}$ & $\begin{array}{c}-0.150^{* * *} \\
(0.043)\end{array}$ & $\begin{array}{c}-0.151^{* *} \\
(0.070)\end{array}$ \\
\hline$\times 2019 Q 3$ & $\begin{array}{c}-0.200^{* * *} \\
(0.044)\end{array}$ & $\begin{array}{c}-0.166^{* * *} \\
(0.044)\end{array}$ & $\begin{array}{c}-0.250^{* * *} \\
(0.069)\end{array}$ \\
\hline$\times 2019 Q 4$ & $\begin{array}{c}-0.087^{*} \\
(0.046)\end{array}$ & $\begin{array}{l}-0.036 \\
(0.047)\end{array}$ & $\begin{array}{l}-0.055 \\
(0.072)\end{array}$ \\
\hline Fixed Effects & $c t, p q, c I, I t$ & $c t, p q, c I, I t$ & $c t, p q, c I, I t$ \\
\hline Observations & $4,208,226$ & 4,208,226 & $4,208,226$ \\
\hline
\end{tabular}

Notes: ${ }^{*} \mathrm{p}<10 \%$; ${ }^{* *} \mathrm{p}<5 \%$; ${ }^{* *} \mathrm{p}<1 \%$. Robust standard errors in parentheses, clustered by HS6 product. Average ITE measures are generated using LFTTD data from 2014 through 2016. Fixed effects denoted by country $(c)$, month $(t)$, and HS section $(I)$ and their interactions. All specifications include HS6-calendar quarter $(p q)$ fixed effects. 
Table 14. Export Growth and Import Tariff Exposure:
Regional Sensitivity

\begin{tabular}{lcccccccc}
\hline & $(1)$ & $(2)$ & $(3)$ & $(4)$ & $(5)$ & $(6)$ & $(7)$ & $(8)$ \\
Excluding: & China & $\begin{array}{c}\text { North } \\
\text { America }\end{array}$ & $\begin{array}{c}\text { Central } \\
\text { America }\end{array}$ & $\begin{array}{c}\text { South } \\
\text { America }\end{array}$ & $\begin{array}{c}\text { Europe } \\
\text { Asia }\end{array}$ & $\begin{array}{c}\text { Australia/ } \\
\text { Oceania }\end{array}$ & $\begin{array}{c}\text { Africa } \\
\end{array}$ \\
& & & & & & & \\
\hline $\ln \left(1+\tau_{p c t}\right)$ & $-0.967^{* * *}$ & $-0.695^{* * *}$ & $-0.902^{* * *}$ & $-0.912^{* * *}$ & $-1.409^{* * *}$ & $-0.980^{* * *}$ & $-0.925^{* * *}$ & $-0.921^{* * *}$ \\
& $(0.134)$ & $(0.130)$ & $(0.124)$ & $(0.120)$ & $(0.159)$ & $(0.136)$ & $(0.121)$ & $(0.121)$ \\
$I T E_{p} \times I(>2018 Q 3)$ & $-0.094^{* * *}$ & $-0.089^{* * *}$ & $-0.108^{* * *}$ & $-0.085^{* * *}$ & $-0.088^{* *}$ & $-0.066^{* * *}$ & $-0.086^{* * *}$ & $-0.090^{* * *}$ \\
& $(0.026)$ & $(0.027)$ & $(0.029)$ & $(0.026)$ & $(0.028)$ & $(0.027)$ & $(0.026)$ & $(0.026)$ \\
\hline Observations & $4,093,618$ & $4,005,156$ & $3,338,972$ & $3,743,375$ & $3,102,584$ & $2,975,285$ & $4,046,500$ & $4,037,073$ \\
\hline
\end{tabular}

Notes: * $\mathrm{p}<10 \%$; ** $\mathrm{p}<5 \%$; *** $\mathrm{p}<1 \%$. Robust standard errors in parentheses, clustered by HS6 product. All regressions include country-time, country-section, section-time, and HS6calendar quarter fixed effects. Each column excludes one region at a time in the following order: North America, Central America, South America, Europe, Asia, Australia and Oceania, Africa, and China. The regions are defined by the Census Bureau (https://www.census.gov/foreigntrade/schedules/c/countrycode.html).

\section{Table 15. Export Growth and Import Tariff Exposure: Additional Robustness Checks}

\begin{tabular}{lccc}
\hline & $(1)$ & $(2)$ & $(3)$ \\
& No Retaliation & Concorded & Cost Share \\
\hline$\Delta \ln \left(1+\tau_{p c t}\right)$ & - & $-0.916^{* * *}$ & $-0.957^{* * *}$ \\
& & $(0.120)$ & $(0.122)$ \\
$I T E_{p} \times I(>2018 Q 3)$ & $-0.082^{* * *}$ & $-0.089^{* * *}$ & \\
$I T E_{p c}^{\text {Cost }} \times I(>2018 Q 3)$ & $(0.026)$ & $(0.026)$ & $-0.097^{* *}$ \\
& & & $(0.046)$ \\
\hline Fixed Effects & $c t, p q, c I$, It & $c t, p q, c I$, It & $c t, p q, c I, I t$ \\
Observations & $4,060,043$ & $4,304,696$ & $4,131,358$
\end{tabular}

Notes: $* \mathrm{p}<10 \%$; ${ }^{* *} \mathrm{p}<5 \%$; $* * * \mathrm{p}<1 \%$. Robust standard errors in parentheses, clustered by HS6 product. Fixed effects denoted by country $(c)$, month $(t)$, and HS section $(I)$ and their interactions. All specifications include HS6-calendar quarter $(p q)$ fixed effects. "No Retaliation" sample drops all export product-country pairs that ever face foreign retaliatory export tariffs in 2018-2019; "Concorded" sample includes additional observations for export product codes that were merged or split through a concordance between 2016 and 2018 due to the 2017 revisions to HS classification. "Cost Share" measure as described in Equation 10. 


\section{A Data Appendix}

Export Data We employ monthly, public-use U.S. export data provided by the U.S. Census Bureau from 2015 to 2019. This data spans a major revision of the HS nomenclature in 2017. To construct time consistent export flows at the 6-digit product level, we concord data from 2017-2019 back to the 2012 revision of the HS using concordances from the UN Statistics Division.

Our baseline sample excludes the products that undergo any merging or splitting of codes. Note, we do not simply merge the data over time and keep unchanged codes. Some 6-digit product codes from a prior revision may continue to be reused in subsequent revisions, but they might be aggregated or split in new ways. We keep track of the codes that undergo any revision where we have to aggregate for consistency. We check the robustness of our main result to adding or dropping these codes in Section 4.5.

Firm-Level Data Details of U.S. firm-level data are described in Section 2.2.

Import Tariff Data We collected data at the 8-digit tariff line level on new tariffs levied by the U.S. from 2018-2019 as part of Sections 201, 232, and 301 investigations.

- Section 201: Solar Products, January 23, 2018. We use the list of products and country exemptions from Presidential Proclamation 9693 (Federal Register, Vol 83, p. 3541) of January 23, 2018.

- Section 201: Washing Machines, January 23, 2018. We use the list of products and country exemptions from Presidential Proclamation 9694 (Federal Register, Vol 83, p. $3553)$.

- Section 232: Steel and Aluminum, March 8, 2018 with subsequent waves adding or dropping countries (see Figure 2). These include the products listed in the Annexes to Presidential Proclamation 9704 (Federal Register, Vol. 83, p. 11619) and Presidential Proclamation 9705 (Federal Register, Vol. 83, p. 11625).

- Section 301: China, wave 1 (July 6, 2018), wave 2 (August 23,2018), and wave 3 (September 24, 2018 and escalated on May 23, 2019). There are many modifications and changes, especially to wave 3 , where products are added and removed from earlier annexes in a series of Federal Register notices. We use an official list provided by the USITC (https://hts.usitc.gov/view/China\%20Tariffs?release=2019HTSARev 20, accessed $1 / 30 / 2020) .{ }^{43}$

Export Retaliation Tariff Data Lists of new retaliatory tariffs levied against U.S. exports by various countries is gathered from destination country sources, following information

\footnotetext{
${ }^{43}$ There are some duties levied at the HS 10-digit level against China, which we aggregated to the HS 8-digit level.
} 
produced for the trade war timeline in Bown and Kolb (2019). Since HS6 is the most disaggregated product category that is consistent across countries, we aggregate these lists to the HS 6-digit level. Tariffs are associated with the month in which they were imposed. The total amount of trade subject to retaliatory tariffs is computed using U.S. export data at the HS 6-digit level in 2017. We include the following retaliation actions:

- Canada, July 2018: Retaliatory tariffs on $\$ 17.8$ billion of U.S. exports. Information on the products facing retaliation ("June 29 list") accessed at https://www.piie.com/s ystem/files/documents/bown-2018-07-05.xlsx.

- China, April 2018: Retaliatory tariffs on $\$ 2.4$ billion of U.S. exports. Raw list of categories accessed at: http://images.mof com.gov.cn/www/201803/201803260859 59196.pdf, with additional information here: https://piie.com/system/files/do cuments/2018-04-09-piie-chart-lu-schott.xlsx.

- China, July 2018. Retaliatory tariffs on $\$ 29.2$ billion of U.S. exports. Information on products facing retaliation ("Tariffs effective July 6") accessed at: https://www.piie .com/system/files/documents/bown-2018-06-22.xlsx

- China, August 2018. Retaliatory tariffs on $\$ 15.3$ billion of U.S. exports. Information on products facing retaliation accessed at: http://images.mof com.gov.cn/www/201 808/20180808201049842.pdf.

- China, September 2019: Retaliatory tariffs on $\$ 51.3$ billion of U.S. exports. Information on products facing retaliation ("Figure 2") accessed at: https://www.piie.com/sys tem/files/documents/bown2018-09-20.zip.

- China, June 2019: Retaliatory tariffs on $\$ 39.8$ billion of U.S. exports. Information on products facing retaliation ("China Tariff Rates", Column M) accessed at: https : //www.piie.com/system/files/documents/bown-jung-zhang-2019-06-12.xlsx.

- European Union, June 2018: Retaliatory tariffs on $\$ 4.2$ billion of U.S. exports. Information on the products facing "immediate retaliation" accessed at https://www.pi ie.com/system/files/documents/bown-2018-06-29.xlsx.

- India, June 2019: Retaliatory tariffs on $\$ 1.3$ billion of U.S. exports. List of affected products accessed at https ://docs . wto.org/dol2fe/Pages/FE_Search/FE_S_S009DP . aspx ? language $=E \& C a t a l o g u e I d L i s t=246009,245254 \& C u r r e n t C a t a l o g u e I d I n d$ ex $=0 \& F u l l$ TextHash=371857150\&HasEngli shRecord=True\&HasFrenchRecord=Tru e\&HasSpanishRecord=True.

- Mexico, June 2018: Retaliatory tariffs on $\$ 4.5$ billion of U.S. exports. Information on the products facing retaliation (group 2) accessed at http://www.dof.gob.mx/nota_d etalle $\cdot$ php? codigo $=5525036 \&$ fecha $=05 / 06 / 2018$.

- Turkey, May 2018: Retaliatory tariffs on $\$ 1.6$ billion of U.S. exports. Information on the products facing retaliation accessed at https://docs.wto.org/dol2fe/Pages/ FE_Search/FE_S_S009-DP. aspx?language=E\&CatalogueIdList=245272\&CurrentCa 
talogueIdIndex=0\&FullTextHash=371857150\&HasEnglishRecord=True\&HasFrench Record=False\&HasSpanishRecord=True.

- Turkey, August 2018: Retaliatory tariffs on $\$ 1.6$ billion of U.S. exports. List is identical to May 2018 list, but rates are increased by different amounts. Information on the products facing retaliation accessed at https://www.resmigazete.gov.tr/eskiler /2018/08/20180815-6.pdf.

\section{B Empirical Aggregation to Export Growth}

To fix ideas, we write down a simple empirical model where exporters may have been affected by import tariffs. We index firms by $i$ and products by $p$. Exporters with positive trade to country $c$ in product $p$ are in the set $\Omega_{p c}$. Firm level export sales in product code $p$ to country $c$ in the absence of import tariffs are given by $\tilde{r}_{i p c t}$. We define an indicator variable $D_{i t}=1$ if any imports of firm $i$ are hit by a new tariff and zero otherwise. We assume that the impact of the import tariff on a firm's export output is potentially heterogeneous and adjusts output by $1-\delta_{i p} \leq 1$. We can interpret $\delta_{i p} \in[0,1]$ as a firm-product specific export trade friction induced by tariffs on its own imports. ${ }^{44}$

For clarity, we drop the product subscript and write observed exports $r_{i c t}$ of any firm to country $c$ as,

$$
r_{i c t}=\left[\left(1-D_{i t}\right)+D_{i t}\left(1-\delta_{i}\right)\right] \tilde{r}_{i c t}=\tilde{r}_{i c t}\left[1-D \delta_{i}\right]
$$

Note that unobserved firm-level exports in the absence of the tariff are $\tilde{r}_{i c t}$. We aggregate over all exporters to obtain the equation for observable aggregate exports to country $c$

$$
\begin{aligned}
R_{c t} & =\sum_{i \in \Omega_{c}}\left[1-D_{i t} \delta_{i}\right] \tilde{r}_{i c t} \\
& =\tilde{R}_{c t}-\sum_{i \in \Omega_{c}} D_{i t} \delta_{i} \tilde{r}_{i c t} \\
& =\tilde{R}_{c t}\left[1-\frac{\sum_{i \in \Omega_{c}} D_{i t} \delta_{i} \tilde{r}_{i c t}}{\tilde{R}_{c t}}\right] \\
& =\tilde{R}_{i c t}[1-\tilde{\delta}]
\end{aligned}
$$

The last line uses that $[1-\tilde{\delta}]$ is a trade weighted average of the heterogeneous export effect of import tariffs on affected firms.

We predict $\delta_{i} \in[0,1]$ so that exports are possibly lower if firms imports are hit by new tariffs, i.e. $[1-\tilde{\delta}]<1$. We cannot do this directly because of unobserved heterogeneity of impact across firms and because exports without the presence of tariffs $\tilde{r}_{i c t}$ in the weights

\footnotetext{
${ }^{44}$ The restriction to $[0,1]$ is a testable assumption. It is feasible that firms hit by an import tariff increase their output.
} 
implied above are unobserved. Instead, we use trade participation measures from 2016, before the new tariffs were likely anticipated or implemented, to construct a set of exposure measures that can identify the effect on exports without knowledge of the trade weights above.

Firm level trade flows can be decomposed into the average exports per firm and deviations from average exports relative to the population of all firms that export to $c$, i.e $r_{i c t}=\bar{r}_{c t}+\left(r_{i c t}-\bar{r}_{c t}\right)$. Note that $R_{c t}=N_{c t} \times \bar{r}_{c t}$, so that total exports is the number of exporters times average exports per firm. Moreover, the number of firms hit by a tariff is given by $N_{c t}^{D}=\sum_{i \in \Omega_{c}} D_{i t}$. So we can write total exports of firms hit by an import tariff as $R_{c t}^{D}=N_{c t}^{D} \times \bar{r}_{c t}^{D}$ where superscript $D$ indicates the total exports, the count of firms, or average export per firm for the set of firms hit by a new tariff.

We obtain an expression for $\tilde{\delta}$ in terms of firm level sub-components as follows

$$
\begin{aligned}
\tilde{\delta} & =\frac{\sum_{i \in \Omega_{c}} D_{i t} \delta_{i} r_{i c t}}{N_{c t} \times \bar{r}_{c t}} \\
& =\frac{\sum_{i \in \Omega_{c}} D_{i t} \delta_{i} r_{i c t}}{N_{c t}^{D} \times \bar{r}_{c t}} \frac{N_{c t}^{D}}{N_{c t}} \\
& =\frac{\sum_{i \in \Omega_{c}} D_{i t} \delta_{i}\left(\bar{r}_{c t}+\left(r_{i c t}-\bar{r}_{c t}\right)\right]}{N_{c t}^{D} \times \bar{r}_{c t}} \frac{N_{c t}^{D}}{N_{c t}} \\
& =\left[\frac{\sum_{i \in \Omega_{c}} D_{i t} \delta_{i}}{N_{c t}^{D}}+\frac{\sum_{i \in \Omega_{c}} D_{i t} \delta_{i}\left(r_{i c t}-\bar{r}_{c t}\right)}{N_{c t}^{D} \times \bar{r}_{c t}}\right] \frac{N_{c t}^{D}}{N_{c t}} \\
& =\left[\bar{\delta}+\frac{1}{N_{c t}^{D}} \sum_{i \in \Omega_{c}} D_{i t}\left[\delta_{i}\left(r_{i c t} / \bar{r}_{c t}-1\right)\right] \frac{N_{c t}^{D}}{N_{c t}}\right. \\
& =B_{t} \frac{N_{c t}^{D}}{N_{c t}}
\end{aligned}
$$

The first four lines are algebra. Then we have the first term in equation (11), where we denote the simple average of the supply chain friction for affected firms by $\bar{\delta}=\frac{\sum_{i \in \Omega_{c}} D_{i t} \delta_{i}}{N_{c t}^{D}}$. The second term in (11) is the total effect on average firm sales, $\delta_{i}$ times a measure of how much higher or lower export sales are at each affected firm relative to the average firm's sales.

The coefficient $B_{t}$ on the share of firms affected by tariffs, $\frac{N_{c t}^{D}}{N_{c t}}$, is the simple average effect $\bar{\delta}$ plus an adjustment factor for the ratio of the affected firms' exports, $r_{i c t}$ in the absence of the friction, relative to the average sales of all firms $\bar{r}_{c t}$. In short, effects of tariffs can be amplified by the second term if the incidence of the tariff is on exporters that are larger than average. As we document in the main text, affected firms were indeed larger than average in multiple dimensions, including exports, for the tariffs of 2018-19. ${ }^{45}$

To handle seasonality in high frequency monthly trade flows, we take log differences in exports relative to the previous year. We assume that in the absence of frictions on a firm's

\footnotetext{
${ }^{45}$ Alternatively, the adjustment could be close to zero if $r_{i c t} \approx \bar{r}_{c t}$ and there was little heterogeneity across firms.
} 
import, trade has a standard gravity form where $\ln R_{p c t}=\alpha_{c}+\alpha_{p}+\alpha_{t}+\theta \ln \tau_{p c t}$. That is, aggregate bilateral export flows, $\ln R_{p c t}$, can be decomposed into fixed effects for destination $c$, time $t$, and product specific bilateral trade frictions, $\tau_{p c t}$, such as retaliatory export tariffs.

If exporters are responding to tariffs on their import bundles, then exports will be reduced by a factor $\tilde{\delta}_{t} \in[0,1]$. We do not observe the contemporaneous and endogenously determined share of affected firms, $\frac{N_{p c t}^{D}}{N_{p c t}}$, or the relative average sales ratios of affected firms, $\frac{\bar{r}_{p c}^{D}}{\bar{r}_{p c}}$, to all firms. Instead, we employ lagged values that are fixed over time at 2016 levels as described in the main text. We assume that the number of exporter in any particular product $p$ does not change much over time such that $N_{p c t} \approx N_{p, 2016}$. The number of affected firms at any point in time from 2018-2019 does change over time such that $N_{p c t}^{D}=\phi_{t} N_{p}^{D}$. Thus we have $\frac{N_{p c t}^{D}}{N_{p c t}}=\phi_{t} \frac{N_{p}^{D}}{N_{2016}}$. Using these expressions and log differences relative to the same month at $t-12$ we obtain

$$
\begin{aligned}
\Delta \ln R_{p c t} & =\theta \Delta \ln \tau_{p c t}+\ln \left[1-\tilde{\delta}_{t}\right]-\ln \left[1-\tilde{\delta}_{t-12}\right]+\alpha_{c t}+\alpha_{p} \\
& \approx \theta \Delta \ln \tau_{p c t}-\tilde{\delta}_{t}+\tilde{\delta}_{t-12}+\alpha_{c t}+\alpha_{p}+\varepsilon_{p c t} \\
& =\theta \Delta \ln \tau_{p c t}-\left(B_{p c t} \frac{N_{p c t}^{D}}{N_{p c t}}-B_{p c, t-12} \frac{N_{p c, t-12}^{D}}{N_{p c, t-12}}\right)+\alpha_{c t}+\alpha_{p}+\varepsilon_{p c t} \\
& \approx \theta \Delta \ln \tau_{p c t}-\Delta B_{p c t} \phi_{t} \frac{N_{p}^{D}}{N_{p, 2016}}+\alpha_{c t}+\alpha_{p}+\varepsilon_{p c t} .
\end{aligned}
$$

We use a log approximation in line 2 and replace the unobserved firm shares with the approximate values described above.

In the main text, we estimate a difference-in-difference. As the expression above shows, the term $\Delta B_{p c t} \phi_{t}$ has country, product and time-heterogeneity. Our estimated coefficients average over the country and product heterogeneity. We use discrete pre- and post-tariff period indicators or quarterly interaction terms to capture two things. First, time indicators account for changing share of affected firms relative to 2016 trade patterns as tariffs are phased in $\phi_{t}$. Second, they allow endogenously determined average exports of affected and unaffected firms included in $B_{p c t}$ to be reflected in changes in the estimated coefficient. 


\section{Table A-1. Exporters Paying Import Tariffs: Supply Chain Incidence}

\begin{tabular}{lccc}
\hline Relationship between exported and imported tariffed product: \\
& $\begin{array}{c}\text { Any Product } \\
\text { Broad } \\
(1)\end{array}$ & $\begin{array}{c}\text { Same HS4 } \\
\text { Baseline }\end{array}$ & $\begin{array}{c}\text { Same HS6 } \\
\text { Narrow }\end{array}$ \\
& $84 \%$ & $43 \%$ & $(3)$ \\
\hline Share of Exports & $24 \%$ & $13 \%$ & $30 \%$ \\
Share of Exporters & & $11 \%$ \\
\hline
\end{tabular}

Notes: "Broad" considers exports of all firms that import at least one product subject to import tariffs. "Baseline" considers firm exports in a HS6 category that shares the same HS4 as firm imports subject to import tariffs. "Narrow" considers only those exports in the same HS6 category as firm imports subject to import tariffs.

Source: Authors' calculations using 2016 LFTTD.

Table A-2. Summary Statistics: Import Tariff Exposure and U.S. Export Growth

\begin{tabular}{lcc}
\hline & Mean & St.Dev. \\
\cline { 1 - 2 }$\Delta$ lnExports $_{p c t}$ & -.0023 & 1.27 \\
Foreign Retaliation $\Delta l n\left(1+\tau_{p c t}\right)$ & & \\
Full Sample (with zeros) & 0.0014 & 0.015 \\
Tariff Increases & 0.13 & 0.07 \\
Import Tariff Exposure & & \\
$I T E_{p}$ & 0.11 & 0.11 \\
$I T E_{p}^{\text {Broad }}$ & 0.55 & 0.13 \\
$I T E_{p}^{\text {Narrow }}$ & 0.05 & 0.06 \\
\hline
\end{tabular}

Notes: ITE measures described in Section 3.

Source: Authors' calculations using 2016 LFTTD, public-use Census Bureau data on U.S. monthly exports. Conditional on a tariff increase for a country-product-month triplet, there are about 46,000 observations, or about $1 \%$ of the sample. 
Table A-3. Export Growth and Import Tariff Exposure Tranches Turned on in Succession

\begin{tabular}{lccc}
\hline Exposure Variable & $I T E_{p}$ & $I T E_{p}^{\text {Broad }}$ & $I T E_{p}^{\text {Narrow }}$ \\
\hline$\Delta \ln \left(1+\tau_{p c t}\right)$ & $-0.911^{* * *}$ & $-0.936^{* * *}$ & $-0.913^{* * *}$ \\
& $(0.120)$ & $(0.121)$ & $(0.119)$ \\
Solar/Washing $(T 1)$ & $-0.716^{* * *}$ & $-0.236^{* * *}$ & $-0.913^{* * *}$ \\
& $(0.151)$ & $(0.079)$ & $(0.117)$ \\
Metals $(T 2)$ & $-0.198^{* *}$ & 0.052 & $-0.276^{* *}$ \\
& $(0.083)$ & $(0.036)$ & $(0.134)$ \\
China $(T 3)$ & $-0.066^{* *}$ & $-0.058^{*}$ & $-0.105^{* *}$ \\
& $(0.028)$ & $(0.032)$ & $(0.045)$ \\
\hline Fixed Effects & $c t, p q, c I$, It & $c t, p q, c I$, It & $c t, p q, c I$, It \\
Observations & $4,208,226$ & $4,208,226$ & $4,208,226$ \\
\hline
\end{tabular}

Notes: ${ }^{*} \mathrm{p}<10 \%$; ${ }^{* *} \mathrm{p}<5 \%$; ${ }^{* *} \mathrm{p}<1 \%$. Robust standard errors in parentheses, clustered by HS6 product. Fixed effects denoted by country $(c)$, month $(t)$, and HS section $(I)$ and their interactions. All specifications include HS6-calendar quarter $(p q)$ fixed effects. T1 refers import tariffs on washing machines and solar products; T2 refer to import tariffs on steel and aluminum; and T3 refers to import tariffs on goods sourced from China. 